\title{
Snowfall in High Southern Latitudes
}

\author{
DAVID H. BROMWICH
}

\author{
Byrd Polar Research Center. The Ohio Stase University, Columbus
}

\begin{abstract}
Precipitation over Antarctica is an important climatic variable whose study has been limited by the frequent inability to discriminate between actual snow precipitation and drifting snow. Recent advances in point precipitation measurements promise to circumvent this problem. In addition, indirect estimates based upon the atmospheric water balance equation provide seasonal precipitation amounts for areas larger than $1 \times 10^{6} \mathrm{~km}^{2}$. For broad-scale studies in the continental interior net snow accumulation closely approximates precipitation. Annual precipitation is relatively high over the marginal ice slopes in relation to amounts in the interior. This meridional distribution is due to the orographic lifting of moist air by the ice sheet. Zonal precipitation variations are related to the quasi-stationary cyclones in the circumpolar low-pressure trough. Most precipitation falls in winter, when the average moisture content of the air is low. The intensity of cyclonic activity is the key factor governing the amount of precipitation and its variations. Precipitation generation in coastal regions is strongly influenced by the fact that poleward moving, moist maritime air masses are deflected by the steep marginal ice slopes to blow parallel to the terrain contours. Direct orographic lifting with accompanying adiabatic cooling is the dominant precipitation formation mechanism inland of the $1-\mathrm{km}$ elevation contour; intrusions of moist air far into the continent are accompanied by southerly winds through a deep tropospheric layer. Above $3000 \mathrm{~m}$ elevation where terrain slopes are gentle, radiative cooling is the primary mechanism by which saturation is maintained within moist air, and thus by which precipitation is formed. Most precipitation at these elevations falls from clear skies. This phenomenon does not differ from precipitation originating in clouds but is a direct result of the low moisture content of the air, and hence ice layers are optically too thin to be visible as clouds.
\end{abstract}

\section{INTRODUCTION}

Apart from the western side of the Antarctic Peninsula, average surface air temperatures along the Antarctic coastline during the warmest summer months are close 10 or lower than the freezing point [Schwerdlfeger, 1984, pp. 228-229]. Thus for most coastal areas, precipitation nearly always falls as snow [Loewe, 1957]. For example, at Wilkes Station, which is situated on the coast of East Antarctica (Figure 1). solid, mixed, and liquid precipitation was observed on $95.8 \%, 2.3 \%$, and $1.9 \%$, respectively, of precipitation occasions during 1965-1967 [Ausiralian National Anlarctic Research Expeditions, 1968, 1969, 1970]. In the interior. precipitation is "always" solid: a very rare exception is described by Schwerdlfeger [1984, pp. 153-156].

Precipitation characteristics at the coast and in the high interior are very different. Coastal snowfall is episodic in association with synoptic scale features such as cyclones and fronts. The high steep edge to the ice sheet generally confines organized storm systems to the coastal areas [Asiapenko. 1964]. In the interior, the proportion of precipitation associated with clouds decreases, and the semicontinuous fall of ice crystals from cloud-free skies becomes progressively more important as elevation increases. At Plateau Station, near the crest of the East Antarctic ice sheet, Radok and Lile [1977] estimated that $87 \%$ of the 1967 precipitation total consisted of ice crystals, the majority of which fell from clear skies [Kuhn, 1970].

Precipitation is an important climatic variable of substantial relevance to many research endeavors. For example, snowfall nourishes the ice sheets; thus precipitation characteris-

\section{Copyright 1988 by the American Geophysical Union.}

Paper number 8R0033.

8755-1209/88/008R-0033\$05.00 tics are key inputs for evaluations of whether the amount of Antarctic ice grows or shrinks and the effect of such changes upon global sea level [e.g., Polar Rescarch Board. 1985]. The topographic control of precipitation amount is a fundamental aspect of the growth and dynamics of ice sheets [e.g., Kellogg, 1975]. Interpretation of paleoenvironmental records extracted from Antarctic ice cores depends upon knowledge of the input precipitation signal [e.g., Bromwich and Weaver, 1983; Jouzel et al., 1983]. By contrast. the latent heat released by precipitation formation over this cold, high continent plays only a small role in the atmospheric heat budget [Rubin, 1962].

In the following sections. the distribution and formation of atmospheric precipitation over all parts of the Antarctic continent other than the Antarctic Peninsula are described. Microphysical aspects of precipitation formation (e.g.. ice nucleation) are discussed only when they are important at the macroscale level. Section 2 outlines the difficulties of making direct precipitation measurements in the Antarctic environment. This is followed in section 3 by a depiction of the spatial and temporal precipitation characteristics. Section 4 describes the broad-scale movements of moist air and the use of water vapor fluxes to estimate seasonal precipitation rates over large areas. Then in section 5 the synoptic mechanisms by which moist air is advected over the continent are presented. Section 6 explores the atmospheric dynanics leading to coastal and interior precipitation.

\section{PRECIPITATION MEASUREMENT}

Routine measurement of precipitation amounts in Antarctica using surface-based collection techniques is a difficult and in many instances an impossible task. Substantial quantities of precipitation usually fall in conjunction with strong surface winds. The upwind presence of a virtually unlimited snowfield may provide a source of recently deposited snow 


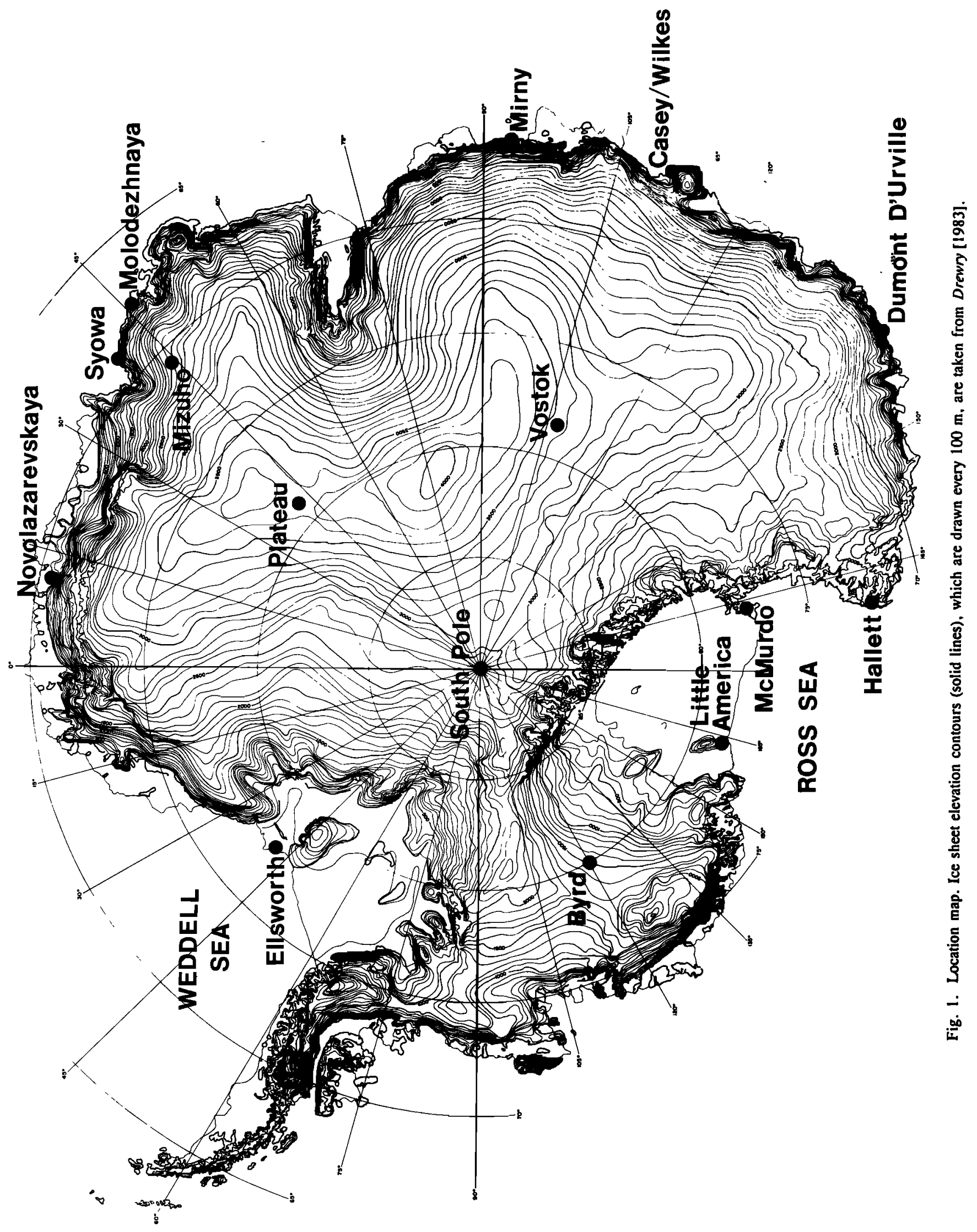


which can be picked up by the wind and transported nearly horizontally. The typical threshold speeds for onset of drifting vary between 7 and $13 \mathrm{~m} \mathrm{~s}^{-1}$ and are dependent on the character of the snow surface [Bryazgin, 1986]. Thus during most large precipitation events the air is filled with both snow that is actual precipitation and snow that was deposited elsewhere and is being transported by the wind. For meaningful precipitation measurements, the relative contributions of these two factors must be determined and the latter excluded.

An additional problem arises in the interior of the continent. Snowfall amounts are very small and are invariably less than the minimum resolution of snow gauges (typically 0.1 $\mathrm{mm}$ water equivalent) when read at 12-hour intervals. Consequently, at South Pole Station, for example, $92 \%$ of months over a 10-year period were credited with only a trace $(0.0 \mathrm{~mm})$ of precipitation [Bryazgin, 1986].

The Arctic and Antarctic Scientific Research Institute in Leningrad has developed methods for correcting mean monthly precipitation totals measured with snow gauges at Soviet Antarctic stations [Bryazgin, 1982, 1986]. Corrections are made for drifting snow blown into the gauge, for variations in the collection area of the gauge due to wind effects on the trajectories of precipitation particles, and for that unrecorded part of the precipitation that moistens the walls of the gauge when melted for measurement. Sublimation losses from the gauge are not evaluated. Sevruk [1981] gives a comprehensive review of methods to correct point precipitation measurements for systematic errors. The first two effects are combined into a wind influence correction which is tabulated as a function of average monthly surface wind speed: at $5 \mathrm{~m}$ $\mathrm{s}^{-1}$ the correction coefficient increases the monthly total by $20 \%$, while for $10 \mathrm{~m} \mathrm{~s}^{-1}$ the total is decreased by $35 \%$ [Bryazgin, 1986]. Measured annual totals of precipitation at the coastal stations of Mirny. Molodezhnaya. and Novolazarevskaya decreased by an average of $30 \%$ upon correction; annual amount at the interior Vostok Station increased by 37\% [Bryazgin, 1982]. For the coastal stations, all of which have marked katabatic wind regimes. the magnitude of the wind correction is some 3 times larger than that of the moistening correction. As the monthly surface wind speeds at these sites during winter are $10 \mathrm{~m} \mathrm{~s}^{-1}$ or more and maximum speeds during storms approach $30 \mathrm{~m} \mathrm{~s}^{-1}$ [Sc/hwerdifeger, 1970], the corrected precipitation amounts should be used cautiously. These data are used in section 3 to describe approximately the seasonal cycle of coastal precipitation. However. precipitation maps for Antarctica [UNESCO. 1978; Bryazgin. 1982] which are derived by merging corrected precipitation amounts from a small number of stations with comprehensive accumulation syntheses are not discussed.

Kobavashi [1985] and Kobayashi ct al. [1985] describe an experimental technique for estimating precipitation rates at Mizuho Station from the vertical profiles of drift snow flux during precipitation. The near-surface environment at this site is characterized by a strong. nearly continuous katabatic wind. The key requirement is to monitor the drift flux high enough above the surface so that the only significant component being sampled is due to the horizontal transport by the wind of precipitating snow particles. A collector at a height of $28 \mathrm{~m}$ on a meteorological tower was generally above the layer of dense blowing snow. The product of the measured snowfall density (kilograms per cubic meter) with the assumed fall speed of the snow particles $\left(0.5 \mathrm{~m} \mathrm{~s}^{-1}\right)$ gives the precipitation rate. Precipitation rates between 0.01 and $0.14 \mathrm{~mm} \mathrm{~h}^{-1}$. (water equivalent) were estimated with a mean of $0.04 \mathrm{~mm} \mathrm{~h}^{-1}$ Using the mean precipitation rate in conjunction with frequency estimates of snowfall occurrence produced an annual precipitation of $140 \mathrm{~mm}$ in 1980 [Kobayashi, 1985]; the seasonal cycle showed a winter (July-September) precipitation maximum and a summer (November-January) minimum.

Takahashi [1985] estimated the 1982 precipitation at Mizuho Station from the drift flux profile by two methods. First, the relationship at $1 \mathrm{~m}$ height between drift flux and wind speed was determined in the absence of precipitation. The increased drift flux during precipitation was assumed to be due to the horizontal transport of precipitation particles. As before, the product of precipitation density and a $0.5 \mathrm{~m} \mathrm{~s}^{-1}$ fall speed gives the precipitation rate. Second, the method described in the previous paragraph was used. Annual precipitation estimates were 230 and $260 \mathrm{~mm}$, respectively, and the seasonal precipitation cycle was similar to that described above. An error analysis gave a 1982 precipitation estimate range of 100 to $300 \mathrm{~mm}$, thus just overlapping with Kobayashi's [1985] value for 1980 .

Salo et al. [1981] give a labor-intensive method capable of measuring precipitation rates characteristic of the south polar region under light winds. Ice crystals were collected by natural sedimentation on small glass slides coated with $0.5 \%$ Formvar solution and replicated. Ice crystal masses are estimated from their measured dimensions. The total mass of ice crystals on the slide divided by the exposure time and by its surface area gives the precipitation intensity. The average summer intensity (during January 1975 and November 1978) was about $0.1 \mathrm{~mm} \mathrm{~h}^{-1}$ at South Pole Station.

\section{PRECIPITATION CHARACTERISTICS}

\section{3.l. Annual Spatial Pattern}

It is fortunate in view of the measurement difficulties outlined in section 2 that numerous glaciological methods [e.g., Lorilis, 1983] are available to measure the surface snow accumulation rate $(B)$, which is closely linked to the precipitation rate $(P)$. These quantities are related by the equation

$$
\overline{\mathrm{B}}=\overline{\mathrm{P}}-\overline{\mathrm{E}}-\underset{\sim}{\nabla} \cdot \int_{0}^{\infty} \mathrm{D} \underset{\sim}{\mathrm{dz}} \quad-\quad \text { runoff }
$$

where the overbar denotes a time average. E the net sublimation (i.e., sublimation minus deposition of hoarfrost) rate. D the density of drift snow, and $\mathrm{V}$ the horizontal wind. Here, sublimation describes the change of phase from solid $\mathrm{H}_{2} \mathrm{O}$ to vapor, and deposition refers to the reverse process. Terms are often given in units of kilograms per square meter per year or, when divided by the density of water, in millimeters of water equivalent per year. The third term on the right side of (1) represents the net deposition rate of snow by drifting. For the continent as a whole, loss of drift snow to the ocean [Loewe, 1970], net sublimation, and liquid runoff [UNESCO, 1978, pp. 484-489] are small in relation to the precipitation. For a first-order discussion of the spatial distribution, precipitation rate will be equated with accumulation rate; this is a good approximation in the central part of the continent. This is followed by a better description of precipitation distribution over the marginal ice slopes. 


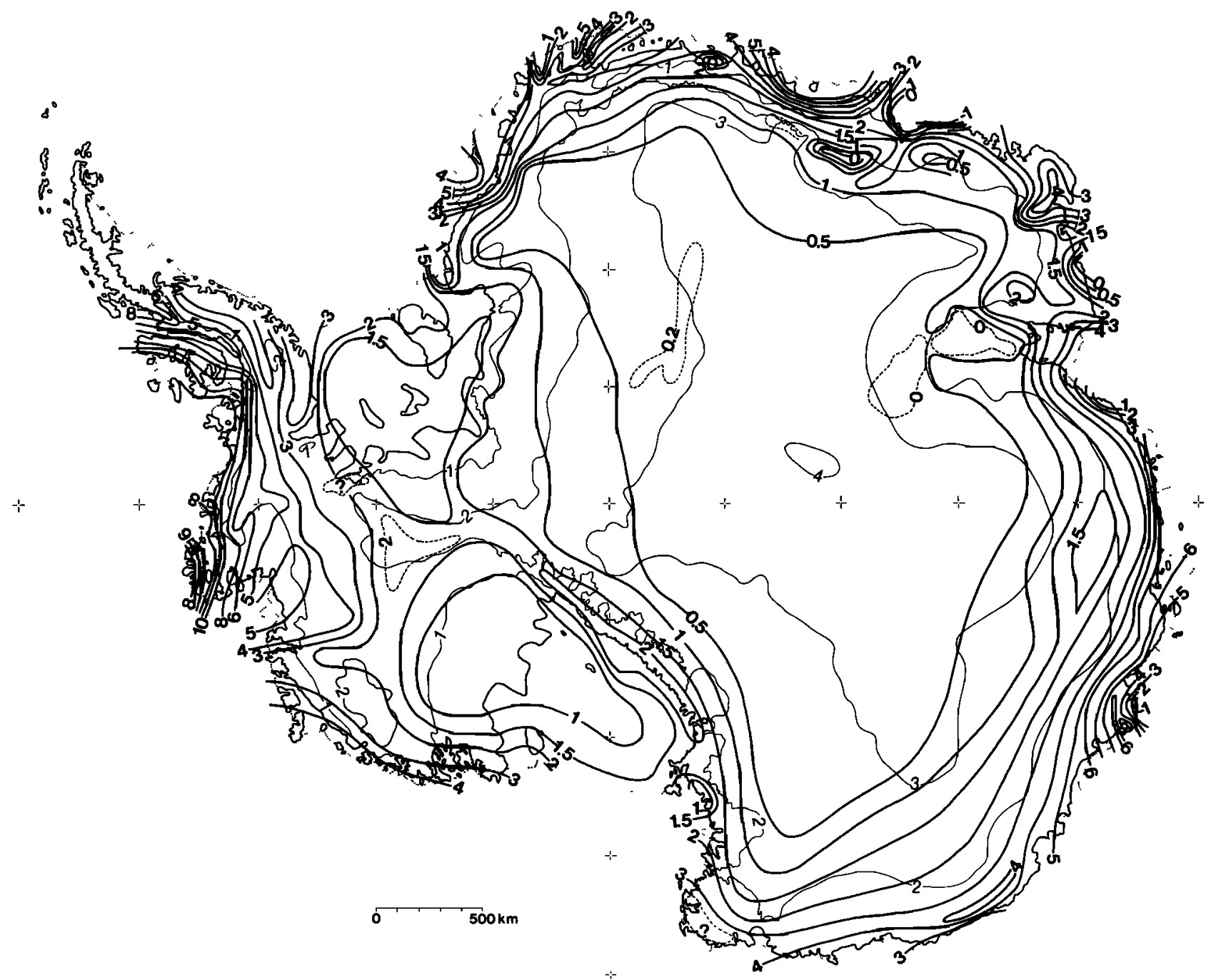

Fig. 2. Annual accumulation map for Antarctica, adapted from Giovineffo and Bentley [1985]. Heavy solid lines are accumulation isopleths in $100 \mathrm{~kg} \mathrm{~m}^{-2} \mathrm{yr}^{-1}$ (or, equivalently, $100 \mathrm{~mm} \mathrm{yr}$ ). Light solid lines are elevation contours in kilometers.

Figure 2 gives an up-to-date assessment of the accumulation rate for Antarctica based upon the work of Giovinetro and Bentley [1985]. On the basis of a comprehensive review of accumulation analyses. Giovinetto and Bull [1987] find that the average Antarctic accumulation rate of Giovinetto and Bentley [1985] is $8 \%$ smaller than the mean fron twelve other analyses published between 1971 and 1985. The general trend is from complicated but generally high values near the coast (in places reaching $800 \mathrm{~mm} \mathrm{yr}^{-1}$ or more) to amounts consistently less than $50 \mathrm{~mm} \mathrm{yr}^{-1}$ for elevations above $3000 \mathrm{~m}$. It is interesting to note that the area characterized by desertlike precipitation rates $\left(<50 \mathrm{~mm} \mathrm{yr}^{-1}\right)$ is twice that estimated in an earlier synthesis by Bull [1971].

Kotlyakov and Sharova [1969] calculated the annual precipitation falling on the trail from Mirny to Vostok. They solved (1) for $\bar{P}$ by using observed values of annual accumulation and estimated values for drift snow transport divergence and net sublimation rate. They ignored runoff effects, which are of significance only at the coast. The calculations are summarized by Table 1. Precipitation rates are large near the coast, decrease rapidly from 750 to $1750 \mathrm{~m}$, and then attain nearly constant values above $2100 \mathrm{~m}$. Precipitation rate is larger than accumulation rate at all elevations: these results are in sharp disagreement with the sketch of these two quantities in the Atlas of Antarctica [1966. p. 96].

Recent work has provided some results substantially different from those presented by Kollyakov and Sharova [1969]. Annual net sublimation rates given by UNESCO [1978. p. 483] decrease to zero about $150 \mathrm{~km}$ from the coast with net deposition prevailing farther inland. Also. the accumulation rates given by Barkov [1974] for the same route for 1970-1973 are much larger than the Kotlyakov and Sharova values from 35 to about $350 \mathrm{~km}$ inland. These discrepancies emphasize the approximate nature of the precipitation calculation.

\subsection{Temporal Variations}

Dolgina and Petrova [1977] tabulate average monthly precipitation totals for various Antarctic stations which generally are derived from at least 5 years of observations. These data are presented in Figure 3 and are arranged by geographic area. The values for Ellsworth, Little America, Wilkes, Mirny, Molodezhnaya, Novolazarevskaya, Vostok, and Byrd are corrected totals measured by precipitation gauges. The 
TABLE 1. Estimated Annual Precipitation Rates Over the Marginal Ice Slopes Along the Mirny to Vostok Traverse Route [Kollyakov and Starova, 1969]

\begin{tabular}{cccccc}
\hline $\begin{array}{c}\text { Distance } \\
\text { from Coast, } \\
\text { km }\end{array}$ & $\begin{array}{c}\text { Elevation, } \\
\mathbf{m}\end{array}$ & $\begin{array}{c}\text { Annual } \\
\text { Accumulation, } \\
\mathbf{m m}\end{array}$ & $\begin{array}{c}\text { Drift Snow } \\
\text { Transport } \\
\text { Divergence, } \\
\mathbf{m m}\end{array}$ & $\begin{array}{c}\text { Net Annual } \\
\text { Sublimation, } \\
\mathbf{m m}\end{array}$ & $\begin{array}{c}\text { Annual } \\
\text { Precipitation, } \\
\text { mm }\end{array}$ \\
\hline $0-7$ & $0-270$ & 577 & -85 & +250 & 742 \\
$7-35$ & $270-750$ & 670 & -55 & +200 & 815 \\
$35-50$ & $750-920$ & 322 & -35 & +200 & 487 \\
130 & 1730 & 80 & +50 & +150 & 280 \\
210 & 2120 & 36 & +70 & +100 & 206 \\
290 & 2500 & 85 & +50 & +50 & 185 \\
350 & 2740 & 160 & +40 & 0 & 200 \\
\hline
\end{tabular}

Amundsen-Scott data are monthly accumulation amounts. Precipitation values for Hallett and McMurdo stations have been derived from visual estimates of precipitation intensity (contained within the present weather portion of surface synoptic observations).

All of these data other than the accumulation values are subject to significant uncertainty due to the wind transport of previously deposited snow (compare section 2); therefore only the major features of the seasonal precipitation cycles will be treated as realistic. At coastal sites in the Ross Sea and Weddell Sea there is a definite precipitation maximum in March and irregular fluctuations otherwise. The October maximum at Ellsworth is probably real. Along the coastal rim of East Antarctica, precipitation rate is highest during the winter and least during the summer: a similar result was ob-
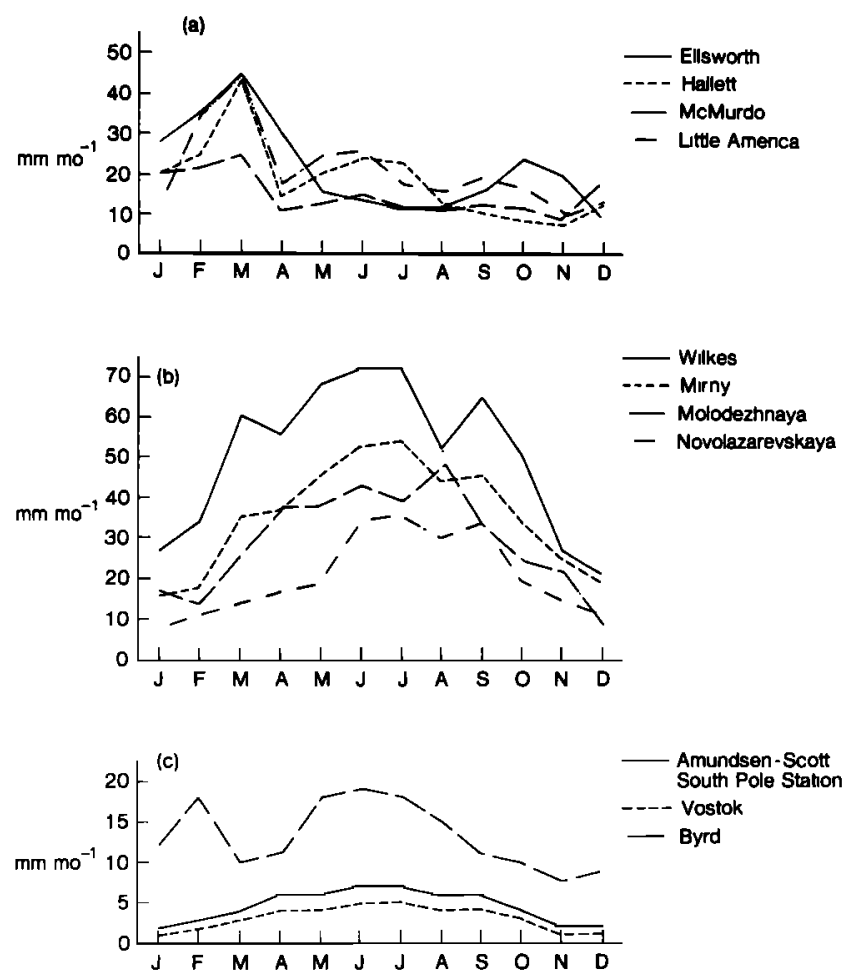

Fig. 3. Mean monthly precipitation amounts for (a) Weddell Sea and Ross Sea embayments. (b) the coast of East Antarctica, and (c) the interior of the continent. Data are from Dolgina and Perrova [1977]. tained by Loewe [1957]. That South Pole and Vostok stations display the same seasonal trend as at the East Antarctic coast suggests that this cycle applies to almost the entire East Antarctic ice sheet. This conclusion is consistent with the seasonal precipitation variation at Mizuho Station (section 2). The seasonal cycle at Byrd Station, which is located near the center of the West Antarctic ice sheet, possesses characteristics of the precipitation curves shown in Figures $3 a$ and $3 b$.

Some idea of the year-to-year variability of point precipitation amounts can be gained from the standard deviations of gauge-measured precipitation totals [Bryazgin, 1986]. These results are summarized by Table 2 . The variability is large. and the coefficient of variation appears to increase as the average precipitation amount decreases. It must be emphasized that these estimates are very approximate because the basic data are subject to the wind effects described in section 2 .

Glaciological methods also yield point estimates of the interannual precipitation variability if it is assumed that the accumulation and precipitation rates vary in parallel. Giovinetto [1964] found that the coefficient of variation is equal to $24 \%$ for Antarctic precipitation rates from 50 to 500 $\mathrm{mm} \mathrm{yr}^{-1}$. Recent studies verify that the scatter around Giovinetto's representative value is substantial. Whillans [1978] obtained a coefficient of variation of $13 \%$ near Byrd Station. while Satow [1985] found values around 50\% inland from Syowa Station.

It is well known, for tropical and mid-latitude continents, that changes in annual precipitation have the same sign over wide areas, and that these anomalies are accompanied by adjacent regions of opposite sign [e.g., Brooks, 1919]; i.e.. over large enough areas the atmosphere tends to compensate for precipitation departures. One approach to estimating the interannual variability of areally averaged precipitation in Antarctica is to examine this quantity for other parts of the Earth with extensive rainfall measurements, and to infer by analogy the likely situation for high southern latitudes. Schwerdtjeger [1951] used data from Tannehill [1947] for the United States to show that as the area of the region increases, the extremes of annual precipitation decrease. Tannehill's [1947] 66 annual values of areally averaged precipitation for most states have been used to calculate the standard deviation of annual precipitation for areas of various sizes. Extension of the United States series to the present day and its representativeness in relation to many other northern hemisphere continental areas can be seen in the data presented by Bradley et al. [1987]. For regions larger 
TABLE 2. Annual Precipitation Variability Estimated From Uncorrecled Totals Derived From Gauge Measurements Collected for 10 or More Years [Bryazgin, 1986]

\begin{tabular}{lccc}
\hline \multicolumn{1}{c}{ Station } & $\begin{array}{c}\text { Annual Average } \\
(\overline{\mathbf{P}}), \mathrm{mm}\end{array}$ & $\begin{array}{c}\text { Standard Deviation }(\mathrm{S}), \\
\mathrm{mm}\end{array}$ & $\begin{array}{c}\text { Coefficient of Variation, \% } \\
(=\mathrm{S} / \overline{\mathrm{P}} \times 100)\end{array}$ \\
\hline Mirny & 622 & 212 & 34 \\
Molodezhnaya & 546 & 114 & 21 \\
Novolazarevskaya & 304 & 126 & 41 \\
Vostok & 26 & 12 & 46 \\
\hline
\end{tabular}

than $\sim 300.000 \mathrm{~km}^{2}$, the coefficient of variation tends to decrease as the area increases (Figure 4). The complicating factor is that most of the largest states have low annual precipitation and high coefficients of variation.

It will be assumed that year-to-year precipitation variations in Antarctica are no larger than the interannual varjations over areas of the same size in the United States. That this may not be too crude an approximation is suggested by spatial variations of climatic variables over the two continents. Antarctica has a relatively homogeneous longitudinal climate but is subject to large latitudinal changes; the United States by contrast is characterized by large longitudinal and latitudinal variations. Figure 4 suggests that for areas larger than, say, $1 \times 10^{6} \mathrm{~km}^{2}$ the interannual precipitation variability is significantly smaller than most of the point values quoted above.

Oerlemans [1981] used accumulation series derived from stratigraphic studies at three sites in Greenland and at South Pole to obtain an approximate estimate of the variability of 30-year mean precipitation rates over Antarctica. The coefficient of variation was found to be around $7 \%$. Unfortunately, the South Pole record [Giovinello and Schwerdtseger, 1966] used by Oerlemans may reflect both the temporal variability of precipitation rate and a local, topographically controlled spatial variation in accumulation rate [Mos/ey-Thompson and

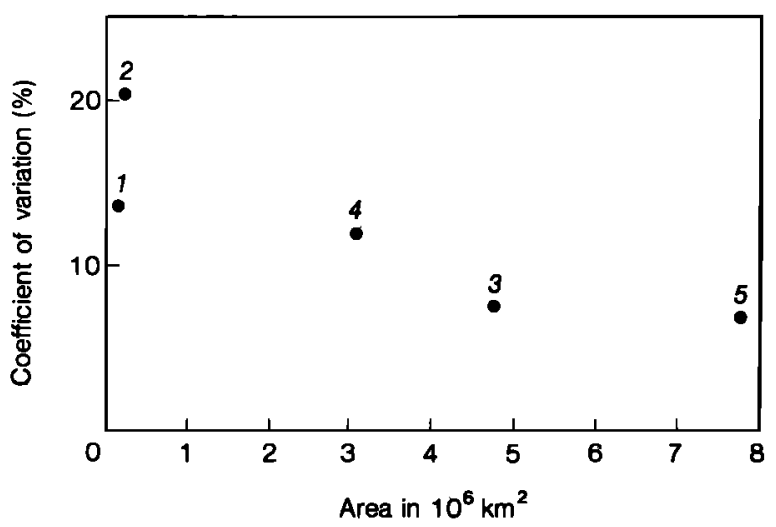

Fig. 4. Coefficient of variation for areally averaged annual precipitation amounts for areas of various sizes in the United States. Precipitation series for 1886 to 1945 is given by Tannehill [1947]. Point 1: average for all individual states (or groups of smaller states defined by Tannehill) east of the Rocky Mountains. Point 2: average for all other states in the contiguous United States, Point 3: for area east of the Rocky Mountains. Point 4: average for remaining part of the contiguous United States, Point 5: average for the contiguous United States.
Thompson, 1982]. An estimate of the coefficient of variation for 30-year average point precipitation amounts also can be obtained from the interannual values quoted above. If the latter coefficient of variation is assumed to be $24 \%$. the 30 -year value equals $24 \times(30)^{-1 / 2}$, or $\sim 4 \%$. This calculation assumes that annual precipitation amounts are uncorrelated. Similar calculations can be performed to obtain coefficients of variation for 30-year areally averaged precipitation amounts.

\section{ATMOSPHERIC WATER VAPOR FLUXES AND INDIRECT PRECIPITATION ESTIMATES}

The temporally and spatially averaged version of the atmospheric moisture balance equation [Peixolo and Oort, 1983] is

$$
\begin{array}{ccc}
\langle\partial \overline{\mathrm{W}} / \partial \mathrm{t}\rangle+\langle\operatorname{div} \overline{\mathrm{Q}}\rangle & =\langle\overline{\mathrm{E}}-\overline{\mathrm{P}}\rangle \\
\mathrm{A} & \mathrm{B} & \mathrm{C}
\end{array}
$$

where precipitable water is

$$
W=\int_{0}^{P_{g}}(q / g) d p
$$

and the horizontal moisture transport vector is

$$
Q=\int_{0}^{P_{s}}(q \underset{\sim}{V} / g) d p
$$

The angle brackets indicate a spatial average, $q$ represents the specific humidity, $g$ is the gravitational acceleration, and $\mathrm{p}$ is the pressure. The vapor budget is established for the entire atmospheric volume overlying the area of interest, and as a result the terms on the left side of (2) are integrated from the surface. where $p=P_{s}$, to the top of the atmosphere, where $p=0$. Equation (2) states that the change in total water vapor stored in the atmospheric column (term A) together with the net horizontal outflow of moisture through the vertical walls surrounding the region (term B) is compensated by the net flux of moisture through the base of the atmospheric column (term $\mathrm{C}$ ). The usual technique used to derive precipitation amounts from (2) is to calculate the terms on the left-hand side from vertical profiles of moisture and winds regularly collected at an array of upper air stations. 
$\langle\mathrm{P}\rangle$ can then be obtained if $\langle\mathrm{E}\rangle$ is known or can be estimated. For typical rawinsonde station arrays (the synoptic network) and usual frequency of balloon launches (once or twice each day) the method is capable of providing good precipitation estimates for areas larger than $1 \times 10^{6} \mathrm{~km}^{2}$ and for periods of 3 months or longer [Rasmusson, 1977]. On seasonal and longer time scales, term $A$ is usually small.

\subsection{Zonal Analyses}

Moisture fluxes for high southern latitudes have been evaluated within the context of global ['Peixolo and Oort. 1983] and hemispheric [Howarth, 1983; Howarth and Rayner, 1986] analyses. Peixolo and Oort [1983] used al] available observations from the global network of rawinsonde stations for the years 1963-1973. As can be seen from their Figure 1, the data base for Antarctica is heterogeneous with record lengths ranging from 1 to 10 years. The spatial coverage is good for the coast of East Antarctica but sparse for West Antarctica and the continental interior, resulting from the distribution of observing points.

Howarth [1983] and Howarth and Rayner [1986] utilized 5 years (1973-1978) and 4 years (1980-1984). respectively. of numerically analyzed fields of atmospheric moisture and wind produced by the Australian Numerical Meteorological Research Center, Melbourne. These analyses incorporate a wide variety of data sources: surface and upper air observations, data from ships and aircraft, and satellite-derived information. The last is particularly valuable over the southern oceans where conventional information is limited.

The Australian analyses have a number of shortcomings which restrict the accuracy of the derived vapor fluxes and their divergencies. Relatively crude vertical resolution is available near the surface [Howarth and Rayner. 1986]; Rasnusson [1977] notes that increased vertical resolution is usually needed to accurately resolve the moisture flux maximum in the lowest layers of the atmosphere. The water vapor values at the $1000 \mathrm{hPa}$ (hectopascals: I $\mathrm{hPa}=100 \mathrm{~Pa}$ ) level are unrealistically large [Karoly and Oort. 1986]. Finally. the Australian syntheses. by virtue of their operational nature. exclude a lot of information normally available in a "research" data set of the type used by Peixolo and Oort [1983]. Even these last data sets for the Antarctic have been found to contain systematic errors, as will be outlined in section 4.2.1.

The zonally averaged version of (2) for seasonal and longer time scales can be expressed as [Peixolo and Oort, 1983]

$$
\frac{1}{a \cos \phi} \frac{\partial}{\partial \phi}\left\{\left[\bar{Q}_{\phi}\right] \cos \phi\right\}=[\bar{E}-\dot{\mathrm{P}}]
$$

where $a$ is the radius of the Earth, $\phi$ is the latitude, $Q_{\phi}$ is the moisture transport in the meridional direction, and the square brackets denote a zonal average. Annual and seasonal [Q ] values obtained by Peixoto and Oort [1983] and Howarth [1983] (plus Howarth and Rayner [1986] where appropriate) are contrasted in Table 3. The values disagree over the southern oceans (north of $70^{\circ} \mathrm{S}$ ) where the conventional data coverage is sparse but agree over Antarctica, south of $70^{\circ} \mathrm{S}$; an average coastal latitude of $71.4^{\circ} \mathrm{S}$ was obtained from the 1970 American Geographical Society map of Antarctica. It should be noted that Howarth's [1983] meridional moisture transports may be underestimated by as much as a factor of 2 for some latitude belts and that the Pcixoto and Oort [1983] values can only be calculated to the nearest kilogram per meter per second.

TABLE 3. Zonal Averages of Meridional Moisture Transport and Meridional Moisture Transport Divergence

\begin{tabular}{|c|c|c|c|c|c|c|c|}
\hline \multirow{3}{*}{$\begin{array}{l}\text { Latitude, } \\
{ }^{\circ} \mathrm{S}\end{array}$} & \multicolumn{7}{|c|}{ Moisture Transport, $\left[\mathbb{Q}_{\phi}\right], \mathrm{kg} \mathrm{m}^{-1} \mathrm{~s}^{-1}$} \\
\hline & \multicolumn{3}{|c|}{ Whole Year } & \multicolumn{2}{|c|}{ DJF } & \multicolumn{2}{|c|}{ JJA } \\
\hline & PO & $\overline{\mathrm{H}}$ & $\overline{\mathrm{HR}}$ & $\mathbf{P O}$ & $\overline{\mathrm{H}}$ & PO & $\mathbf{H}$ \\
\hline 50 & -17 & -10.5 & -10.0 & -17 & -11.4 & -17 & -10.0 \\
\hline 60 & -10 & -6.7 & -6.3 & -8 & -7.0 & -10 & -6.1 \\
\hline 70 & -3 & -3.7 & -3.3 & -2 & -3.2 & -4 & -3.7 \\
\hline 80 & -1 & -1.6 & -1.4 & -1 & -1.9 & -1 & -1.2 \\
\hline 90 & 0 & 0 & 0 & 0 & 0 & 0 & 0 \\
\hline
\end{tabular}

Moisture Transport Divergence. [E - P], $\mathrm{kg} \mathrm{m}^{-2}$

\begin{tabular}{|c|c|c|c|c|c|c|c|c|}
\hline \multirow{2}{*}{$\begin{array}{l}\text { Latitude } \\
\text { Belt, }{ }^{\circ S}\end{array}$} & \multicolumn{4}{|c|}{ Whole Year } & \multicolumn{2}{|c|}{ DJF } & \multicolumn{2}{|c|}{ JJA } \\
\hline & PO & $\mathbf{H}$ & HR & $\mathbf{B R}$ & PO & $\mathbf{H}$ & $\mathbf{P O}$ & $\mathbf{H}$ \\
\hline $50-60$ & -290 & -169 & -160 & -450 & -80 & -47 & -70 & -42 \\
\hline $60-70$ & -270 & -140 & -133 & -320 & -50 & -40 & -60 & -30 \\
\hline $70-80$ & -90 & -108 & -97 & -176 & -10 & -21 & -30 & -29 \\
\hline $80-90$ & -60 & -90 & -77 & -61 & -10 & -26 & -10 & -17 \\
\hline
\end{tabular}

Data sources are PO, 10-year averages from Peixolo and Oort [1983]; H, 5-year averages from Howarth [1983]; HR, 9-year composite calculated from Howarth [1983] and Howarth and Rayner [1986]: and BR, Baumgarther and Reichel [1975]. DJF is December-February, and JJA is June-August. Negative meridional transports are directed poleward. 
Table 3 also lists transport divergence estimates in kilograms per square meter or, equivalently, millimeters. Over Antarctica the Peixolo and Oorl [1983] and Howarth [1983] results are in reasonable agreement. especially on an annual basis. Both analyses agree with the annual divergence value given by Baumgarmer and Reichel [1975] for $80^{\circ}-90^{\circ} \mathrm{S}$; this is derived from somewhat outdated precipitation and sublimation estimates. By contrast, there is a marked disagreement for $70^{\circ}-80^{\circ} \mathrm{S}$.

The atmospheric divergence estimates can also be compared with the recent annual accumulation analysis shown in Figure 2. The accumulation for $80^{\circ}-90^{\circ} \mathrm{S}$ was found from Figure 2 to be $82 \mathrm{~kg} \mathrm{~m}^{-2} \mathrm{yr}^{-1}$, and the value for the entire continent (excluding the northern half of the Antarctic Peninsula) is $143 \pm 14 \mathrm{~kg} \mathrm{~m}^{-2} \mathrm{yr}^{-1}$ [Giovinetro and Bentley, 1985]. Because much of the $80^{\circ}-90^{\circ} \mathrm{S}$ region overlies the high plateau of East Antarctica. it will be assumed following the analysis of UNESCO [1978] that drift snow transport divergence. sublimation rate. and runoff are small in relation to $\overline{\mathbf{P}}$; this assumption also applies for the entire continent. Thus by combining (1) and (3) the moisture transport divergence equals $-[\mathrm{B}]$. As was found in the previous paragraph, the atmospheric and surface-derived annual divergence estimates for $80^{\circ}-90^{\circ} \mathrm{S}$ are in agreement. Bryan and Oort [1984] calculated, from the same data as were used by Peixoto and Oort [1983], that the annual mean transport divergence for Antarctica was $-44 \mathrm{~kg} \mathrm{~m}^{-2} \mathrm{yr}^{-1}$. The magnitude of this estimate is only $30 \%$ of that derived from the accumulation analysis $\left(-143 \mathrm{~kg} \mathrm{~m}^{-2} \mathrm{yr}^{-1}\right)$. Considering that the two atmospheric analyses are rather similar over Antarctica and that the computed divergences for $80^{\circ} .90^{\circ} \mathrm{S}$ are reliable. it appears that the atmospheric divergences for $70^{\circ}-80^{\circ} \mathrm{S}$ are significantly in error.

However, both atmospheric analyses yield larger poleward water vapor transports and larger transport convergence rates between $70^{\circ}$ and $80^{\circ} \mathrm{S}$ in winter (June, July, and August) than in summer (December, January, and February). as observed (section 3.2). Bryan and Oort [1984] find a maximum convergence rate for Antarctica in spring (September-November).

In the preceding discussion, the recent global water vapor flux study by Chen [1985] has been omitted. In general, the contours and tabulations in the analysis are too coarse to reveal significant detail over Antarctica. Also, the summer water vapor fluxes derived for parts of East Antarctica $\left(75^{\circ}\right.$ $90^{\circ} \mathrm{S}, 90^{\circ}-150^{\circ} \mathrm{E}$ ) are grossly in error. Fluxes characteristic of the coastal regions were obtained for this elevated plateau.

\subsection{Regional Siudies}

4.2.1. East Antarctica. Bromwich [1979] conducted a study of the atmospheric water balance over East Antarctica using rawinsonde data for 1972 . The atmospheric budget volume was designed around the distribution of aerological stations: there is good spatial resolution along the coast. but a data void exists in the interior. As the latitude along the coast of East Antarctica does not change very much, it was approximated by a parallel of latitude and made the northern boundary of the budget domain. It was inferred that because the crest of the ice sheet is a cold, high area with generally light winds in the free atmosphere [Parish and Bromwich. 1986], the moisture transport must be small. The ridge line was approximated by another parallel and made the southern boundary of the domain. The eastern and western meridional boundaries were determined by the available upper air stations and by the re- quirement to locate them predominantly over the ice sheet. This budget volume is arranged so that the meridionally moving moist air masses producing Antarctic precipitation are well sampled as they cross the coast. but the fluxes across the other, largely unmonitored boundaries are likely to be small. With these simplifications, (2) for seasonal time scales becomes

$$
\left(A_{\partial N}^{-1}\right) \underset{0}{\int}\left\{\int_{s}^{P_{s}}(\overline{q v} / g) d p\right\} d l=\langle\bar{E}-\overline{\mathbf{P}}\rangle
$$

where $A$ is the area over which the precipitation is to be determined. $v$ is the meridional wind component which is positive to the north, and $\partial \mathrm{N}$ indicates integration along the northern boundary of the domain, i.e.. along the coast. Apart from one important exception, which will be discussed below, this equation produces reasonable estimates of $\langle\overline{\mathrm{E}}-\overline{\mathrm{P}}\rangle$.

With E set approximately to zero (see below). equation (4) says that the net southward transport of water vapor across the East Antarctic coastline is the source for ice sheet precipitation. Furthermore. this transport convergence is primarily forced by the topography. It is for this reason that Antarctic accumulation rates are usually a marked function of elevation [Muszunski and Birchficld. 1985]. despite the influence of many other factors. such as complicated upstream topography for parts of West Antarctica [Rubin and Giovinetlo, 1962].

It is widely known that the uncertainty of radiosonde humidity observations increases as the temperature decreases [e.g., Loewe, 1957]. This circumstance has less effect than might be expected because large poleward fluxes of water vapor, which make a major contribution to the net poleward moisture transport across the East Antarctic coastline, are accompanied by above-average temperatures and thus more reliable humidity measurements. A fundamental assumption of this work is that. although individual soundings may be significantly in error, the moisture measurements are not consistently biased in favor of higher or lower values. A limited test of this assumption was conducted by comparing average specific humidities measured at neighboring sites using different moisture sensors; the test was restricted to levels well above the surface which are probably unaffected by local boundary layer influences. Comparison of Figures 1 and 5 shows that Syowa and Molodezhnaya stations are $300 \mathrm{~km}$ apart and subject to the same free atmospheric circulation pattern. Their annual average values below the $500 \mathrm{hPa}$ level agreed to better than $0.1 \mathrm{~g} \mathrm{~kg}^{-1}$, which is equivalent to a fractional contrast smaller than 0.1 . In the layers where most water vapor resides, neither site measured consistently higher $q$ values, thus supporting the above assumption.

A special effort was made to ensure that the best possible data set was available for analysis. Good resolution near the surface was used to resolve the low-level coastal moisture flux maximum; vertical resolution was $50 \mathrm{hPa}$ up to the $800-\mathrm{hPa}$ level and then $100 \mathrm{hPa}$ to the $300-\mathrm{hPa}$ level. Also, it was found that the frequent failure at some coastal stations (where $\mathrm{Q}_{\phi}<0$ ) to launch rawinsonde balloons during strong wind periods [Bromwich, 1978] resulted in a 30\% underestimate of the poleward moisture transport; estimates of missing $Q_{\phi}$ values were obtained from regression equations between $Q_{\phi}$ and surface values of $v$ and $q$.

Figure 5 shows the distribution of rawinsonde stations used in this analysis together with the annual moisture transport 


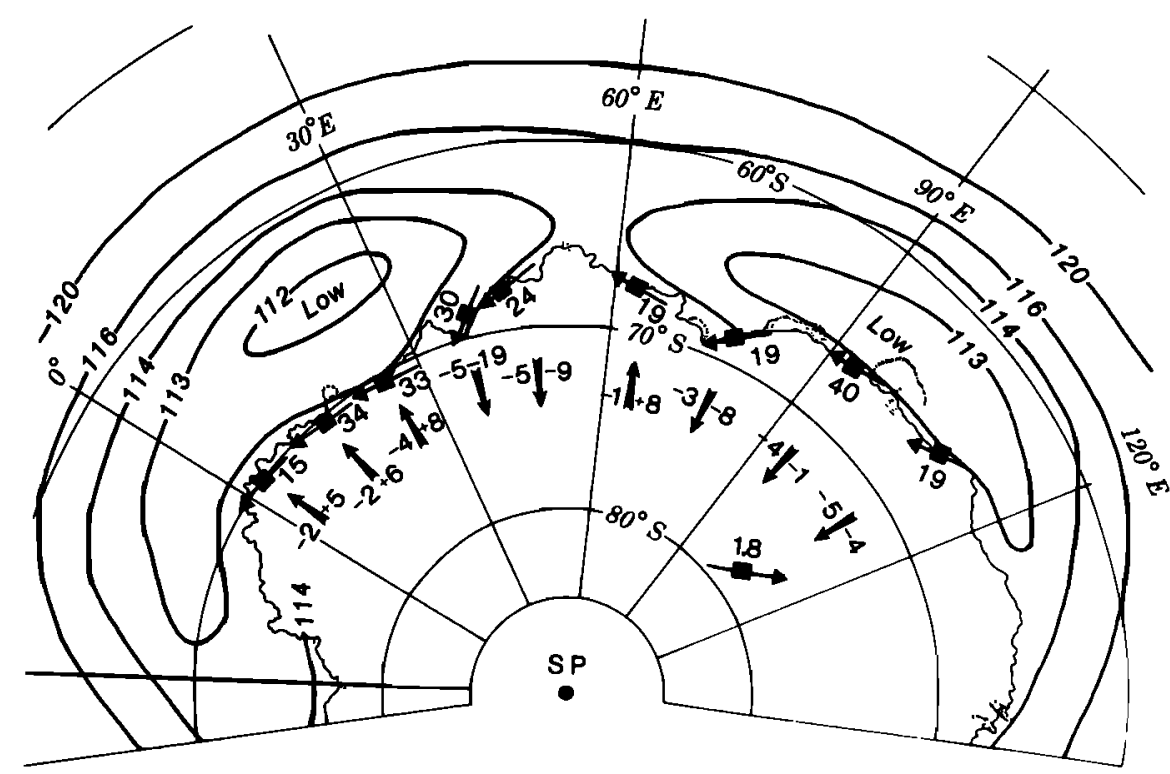

Fig. 5. Annual moisture transport in relation to the mean atmospheric circulation. The solid squares identify rawinsonde stations, and the attached arrows show the direction of annual transport. The transport magnitude in kilograms per meter per second is entered next to each arrow. The solid arrows give the direction of the meridional component of annual transport at the coastal station just to the north; the eddy contribution is listed on the left side and the steady part on the right side of each solid arrow. The solid lines are annual geopotential height contours in dekameters of the $850-\mathrm{hPa}(=85 \mathrm{kPa})$ surface [from Taljaard et al., 1969].

vectors (Q) obtained for 1972. Also included in Figure 5 are climatological contours of geopotential height at the $850-\mathrm{hPa}$ level according to Taljaard et al. [1969]. The geostrophically balanced motion, which is parallel to the contours and is clockwise around low centers. gives a good estimate of the time-averaged circulation at the level of maximum moisture flux. The two cyclones reflect the frequent presence of depressions which are mostly dissipating [e.g., Streten, 1980]. The transport vectors are generally parallel to the coastline. due to the conjunction in the lower troposphere of the circumpolar easterlies and most of the water vapor. The transport values are larger at the longitudes of the cyclonic centers.

The meridional moisture transport can be broken into mean (term A) and eddy (term B) coniponents:

$$
\bar{Q}_{\phi}=\int_{0}^{P_{s}}(\overline{q v / g}) d p=\int_{0}^{P_{s}}(\bar{q} v / g) d p+\int_{0}^{P_{s}}\left(q^{\prime} v^{\prime} / g\right) d p
$$

where $v=\bar{v}+v^{\prime}$ and $q=\bar{q}+q^{\prime}$. The first term describes the meridional transport due to the time-averaged north-south airflow, and the second the transport due to passing cyclones [Peixolo and Oort, 1983]. Here $\mathrm{P}_{\mathrm{s}}$ refers to the time-averaged surface pressure.

The annual means of the two contributions have been plotted in Figure 5 to the south of each coastal station; the heavy arrows give the directions of the total meridional transports with the mean components written to the right and the eddy terms to the left. The total transport shows a consistent pattern of poleward and equatorward values associated with each quasi-stationary cyclone. All the eddy components are directed poleward and show a consistent west to east increase such that the largest values lie to the east of the cyclonic centers. The preceding observations suggest that the coastal pattern of moisture transport is closely linked to the offshore cyclonic vortices; the seasonal variation of zonal moisture transports also shows the same spatial organization. Streten [1968] for a limited period noted the association between coastal sections with a high frequency of cyclonic dissipation and regions just to the east with enhanced annual accumulation. This finding is consistent with the view that most cyclonic precipitation occurs in poleward moving moist air masses east of the vortex center. Consequently, moisture balance calculations were carried out for each cyclonically influenced region (covering the longitudes $0^{\circ}$ to $55^{\circ} \mathrm{E}$ and $55^{\circ} \mathrm{E}$ to $110^{\circ} \mathrm{E}$ ) as well as for the whole domain.

When averaged in longitude. the large mean meridional transports of opposing sign tend to cancel, and the eddy transports dominate (Table 4). This result is consistent with the work of Pcixolo and Oort [1983]. who find this to be the case for zonal averages. Table 4 shows that the results for the two longitudinal sectors are similar, with the mean component contributing about $25 \%$ of the total poleward transport across the coastline. It is interesting to note that the annual longitudinal averages from $0^{\circ}$ to $110^{\circ} \mathrm{E}$ are similar to the zonal annual average transports obtained by Peixoto and Oort [1983] and Howarth [1983]; the data base for all analyses is by far the best along the East Antarctic coast. Both Bromwich [1979] and Pcixoro and Oort [1983] find a much stronger poleward transport in winter than in summer.

The seasonal and annual precipitation amounts (revised from Bromwich [1979]) were calculated from the full atmospheric water balance equation:

$$
\begin{aligned}
\langle\overline{\mathrm{P}} \tau\rangle & =-\tau\left\{\int_{\partial \mathrm{N}} \overline{\mathrm{Q}}_{\phi} \mathrm{dl}-\int_{\partial S} \overline{\mathrm{Q}}_{\phi} \mathrm{dl}-\int_{\partial W} \overline{\mathrm{Q}}_{\lambda} \mathrm{dl}\right. \\
& +\int_{\partial \mathrm{E}} \overline{\mathrm{Q}}_{\lambda} \mathrm{dl} / / \mathrm{A}+<\overline{\mathrm{E}} \tau>-<\mathrm{W}_{\mathrm{f}}-\mathrm{W}_{\mathrm{i}}>
\end{aligned}
$$


TABLE 4. Longitudinally- Averaged Meridional Moisture Transports at Coast of East Antarctica

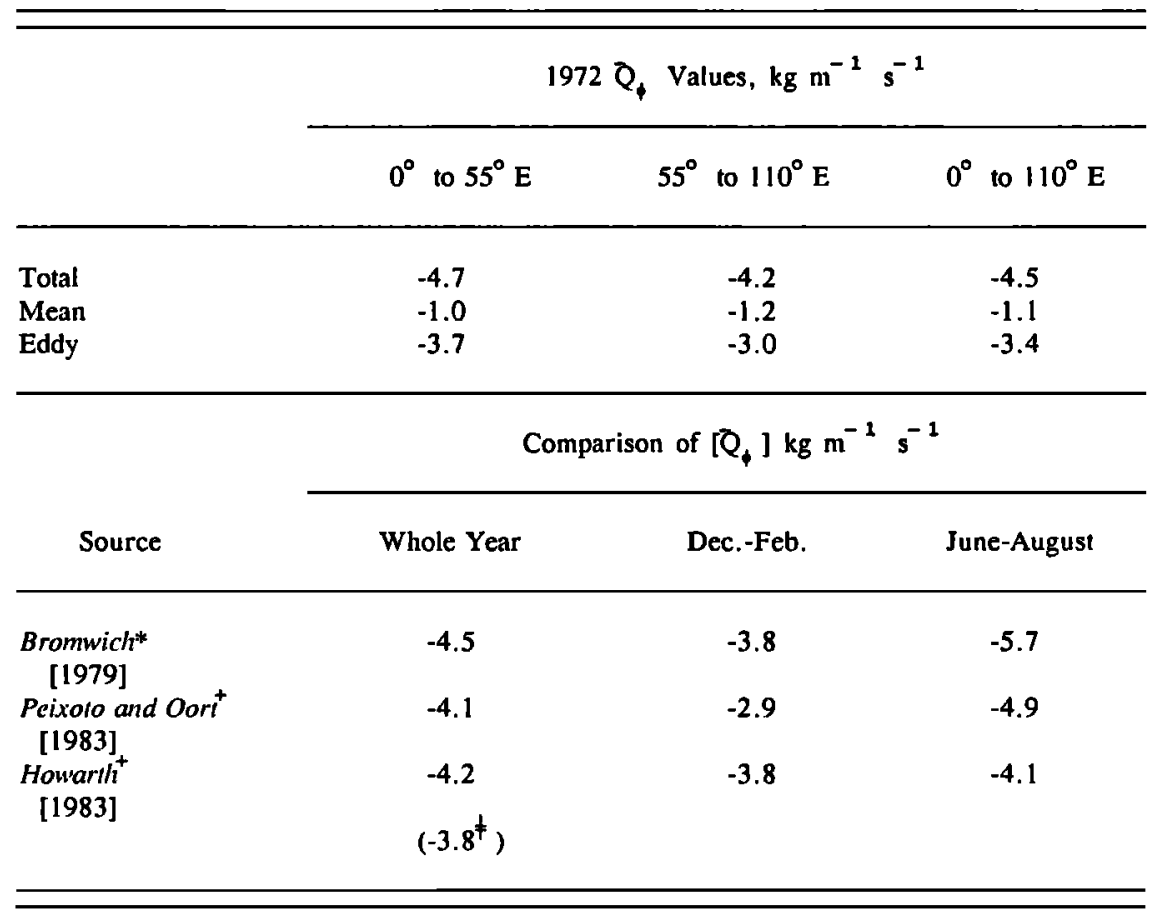

*Average along $31 \%$ of the latitude circle at $68.5^{\circ} \mathrm{S}$ for 1972 .

+ Multiannual zonal averages linearly interpolated to $68.5^{\circ} \mathrm{S}$.

\# Nine year composite value calculated from Howarth [1983] and Howarth and Rayner [1986].

where $W_{i}$ and $W_{p}$ are the values of precipitable water at the beginning and end of time interval $\tau$, respectively, and $\partial W$ (etc.) denotes integration along the western boundary of the budget domain. The net sublimation and storage change terms were estimated and found to be very sniall. The meridional transport at the coast $(\partial N)$ was calculated from rawinsonde data as discussed previously. The transport integrals along the southern. western, and eastern boundaries were primarily estimated from the climatological data given by Taljaard ef al. [1969] and Jenne el al. [1971]. Below $2500 \mathrm{~m}$ elevation along $\partial W$ and $\partial E$. coastal $Q_{\lambda}$ values were applied with a correction for that part of the flux profile cut off by the topography. Measured transports at Vostok were applied along $\partial S$ and $\partial E$ within $300 \mathrm{~km}$ of the station. an average radius of station influence. As expected. the meridional transport across the coast dominated the budget for all sectors. However, the westward transport across the western boundary was a large term for the longitudes $0^{\circ}$ to $110^{\circ} \mathrm{E}$ and $0^{\circ}$ to $55^{\circ} \mathrm{E}$. This occurred because the parallel approximating the coastline lies well to the north of the marginal ice slopes along the Greenwich meridian and because $\left|\bar{Q}_{\lambda}\right|$ at the coast is large. Equatorward transport across $\partial S$ associated witl the circumpolar vortex generally contributed less than $20 \%$ of the precipitation in the $55^{\circ}$ to $110^{\circ} \mathrm{E}$ area.

Table 5 lists the precipitation values calculated from the moisture budget. Also given are the standard errors of these estimates which allow for the effect of temporal persistence. The annual values are determined with a statistical uncertainty of $20 \%$ for $0^{\circ}$ to $110^{\circ} \mathrm{E}$ and $55^{\circ}$ to $110^{\circ} \mathrm{E}$ and $31 \%$ for $0^{\circ}$ to $55^{\circ} \mathrm{E}$. Clearly, analysis of several years of data is required to characterize the climatological situation, as only then will statistical uncertainty be significantly reduced and interannual variability taken into account.
Also included in Table 5 are multiannual precipitation amounts estimated from the snow accumulation synthesis of Bull [1971] using (1). Similar to UNESCO [1978] net sublimation. runoff, and loss of drift snow across the edge of the ice sheet were estimated and found to be small in relation to the accumulation. Their total effect was to make the precipitation rate $6 \%$ larger than the accumulation rate. Net sublimation contributes in the same manner to precipitation amounts estimated from both the atmospheric water balance and the accumulation synthesis. As a result, uncertainties in the net sublimation rate arising because of the recent sublimation measurements at Mizuho Station [Fujii and Kusunoki, 1982; Schwerdtfeger, 1984. pp. 195-196] do not affect the precipitation comparisons in Table 5. Parish and Bromwich [1987] have shown that the cold air drainage across the edge of the East Antarctic ice sheet is concentrated into several narrow zones. Because these regions of strong. persistent katabatic winds are not well sampled by the present observational network and because they make a significant contribution to estimates of drift snow loss from the ice sheet, the accumulation-derived precipitation estimates in Table 5 should probably be increased by a few percent. It appears that 1972 precipitation values for $0^{\circ}$ to $110^{\circ} \mathrm{E}$ and $55^{\circ}$ to $110^{\circ} \mathrm{E}$ are significantly smaller than typical values obtained from glaciological data.

Seasonal precipitation estimates for the regions $0^{\circ}$ to $55^{\circ} \mathrm{E}$ and $55^{\circ} \mathrm{E}$ to $110^{\circ} \mathrm{E}$ show both similarities and differences. The standard errors of seasonal precipitation amounts are relatively constant for each region. As a result, summer precipitation amounts are not well resolved. but maxinum seasonal amounts are estimated with uncertainties of 24 to $38 \%$. The differing behavior in 1972 of the two areas is illustrated by the maximum precipitation falling in spring and in winter. That the precipitation rate is highest during winter for $55^{\circ}$ 
TABLE 5. Precipitation Amounts Estimated From the 1972 Atmospheric Water Balance

(Moisture Budget) and From the Multiannual Accumulation Analysis of Bull [1971]

\begin{tabular}{llllll}
\hline Source & Whole Year & DJF & MAM & JJA & SON \\
\hline
\end{tabular}

$0^{\circ}$ to $110^{\circ} \mathrm{E} .68 .4^{\circ}$ to $78.2^{\circ} \mathrm{S}$

$\begin{array}{llllll}\text { Moisture budget } & 113 \pm 23 & 17 \pm 12 & 27 \pm 12 & 45 \pm 11 & 24 \pm 9 \\ \text { Bull }[1971] & 152 & & \end{array}$

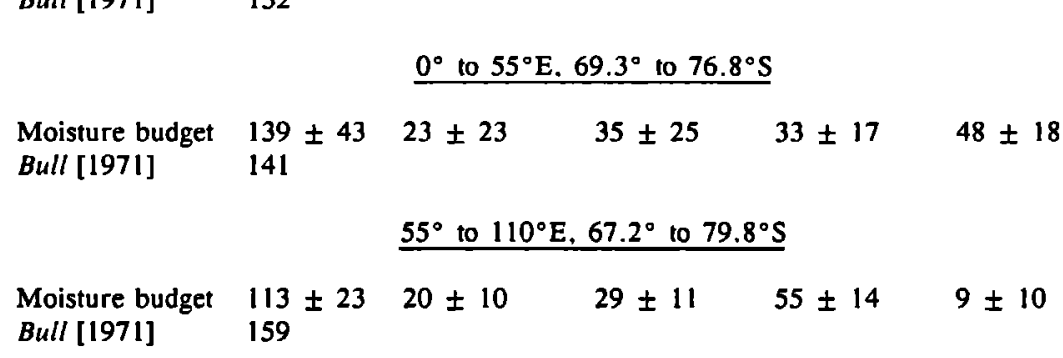

Data are given as kilograms per square meter. For the moisture budget values, standard errors are also given. DJF, December-February; MAM, March-May; JJA. June-August; and SON, Seprember-November.

to $110^{\circ} \mathrm{E}$ (and $0^{\circ}$ to $110^{\circ} \mathrm{E}$ ) is consistent with the average seasonal precipitation cycle identified in section 3.2 .

At this point, it is appropriate to remark that the precipitation cycle does not go hand-in-hand with the temperature cycle. In fact, for East Antarctica, most snow falls at the coldest time of the year. due to the dominance of the intensity of the atmospheric circulation over the moisture-holding capacity of the air in determining precipitation amounts. Thus, relationships between annual precipitation amount and annual temperature found at individual sites [Limbert, 1984] probably arise because of the nature of the atmospheric circulation and may not be generally applicable.

4.2.2. West Antarctica. This topic has atteady been reviewed [Bromwich, 1984], and therefore only a brief discussion will be presented. Note that an atmospheric water balance (such as that presented in section 4.2.1) canno be established from rawinsonde obser ations because no actological station has operated along the coast between $70^{\circ} \mathrm{W}$ and $160^{\circ} \mathrm{W}$.

Leflau [1969] constructed a mass budget for the Antarctic atmosphere and estimated the water vapor content. From a comparison of the resulting mean meridional moisture transports with annual accumulation amounts, it was shown that a substantial fraction of vapor flow into the continent occurs over West Antarctica in conjunction with the circumpolar vortex. It was inferred that the eddy moisture transports were of equal importance to those associated with the mean meridional circulation. The strong synoptic influence accompanying the irregular penetration of cyclones into the interior of the ice sheet suggests that the interannual precipitation variability is fairly high [Lettau. 1969; Vickers, 1966], at least on the ice slopes facing the South Pacific Ocean.

Rubin and Giovinetto [1962] calculated 1958 moisture fluxes and lifted condensation levels at $850 \mathrm{hPa}$ and $700 \mathrm{hPa}$ for Ellsworth and Little America, located to the east and west. respectively. of the ice sheet. and at $700 \mathrm{hPa}$ for Byrd Station, in the ice sheet interior. When these data were considered in relation to the topography, the decrease in annual snowfall over West Antarctica from east to west and from north to south was explained.

\subsection{Moisture Source for Antarctic Precipitation}

On the basis of atmospheric water balance studies [e.g., Peixalo and Oort, 1983: Howarth and Rayner, 1986], it is usually inferred that the water vapor which precipitates in Antarctica comes from the huge atmospheric source region in tropical and subtropical latitudes $\left(\sim 8^{\circ} \mathrm{S}-40^{\circ} \mathrm{S}\right)$. By contrast, exanination of stable oxygen isotope ratios in Antarctic precipitation suggests that the vapor originates much farther poleward. Bromwich and Weaver [1983] analyzed a limited isotopic data set from Syowa Station [Kalo, 1978] and concluded on the basis of the seasonal isotopic cycle that the primary moisture source region "for this site is located in the vicinity of fhe $0^{\circ} \mathrm{C}$ or $1^{\circ} \mathrm{C}$ sea surface isotherm. Annual average latitudes of these features for $20^{\circ}-60^{\circ} \mathrm{E}$ are $58^{\circ}$ and $55^{\circ} \mathrm{S}$, respectively. Robin and Yohnsen [1983], also from evaluation of seasonal (sotopic variations. obtained an ill-defined source region bounded by latitudes $38^{\circ} \mathrm{S}$ and $62^{\circ} \mathrm{S}$. Regardless of the precise location, it is clear that the moisture source found by isotopic studies is much farther south than that resolved by atmospheric water balance investigations. The isotopic results can probably be extended to the entire continent, given the fairly constant seasonal isotopic range [Robin and Johnsen, 1983]. It should be noted that enough moisture evaporates [Peixolo and Oort, 1983, Figure 22] between the northern edge of the pack ice (averaging $65^{\circ} \mathrm{S}$ ) and $62^{\circ} \mathrm{S}$ to supply all the precipitation falling on Antarctica.

This apparent conflict can be resolved if the nature of the information provided by these two methods of analysis is properly understood. The atmospheric water balance approach does not describe the behavior of individual moist air parcels, but rather the net effect of water substance changes within an atmospheric volume. Stable isotopic ratios in precipitation represent a composite of the histories of the moist air parcels from which the precipitate formed [Dansgaard, 1964]. Robin [1983] succintly describes the combined isotopic-vapor transport cycle across the southern oceans. As water vapor which evaporates in the subtropics moves poleward, the evaporation from the surface does not completely replace the vapor 
which has precipitated out. As a result, there is a net meridional moisture transport convergence, and the precipitate becomes progressively more depleted in the heavier isotope of oxygen $\left({ }^{18} \mathrm{O}\right)$. The isotopic results quoted in the previous paragraph indicate that the moisture has been replaced at least once during air mass transit from subtropical to polar latitudes.

By combining observed atmospheric vapor fluxes with a simple simulation of isotopic fractionation. Fisher and Alt [1985] inferred that all moisture source areas between $30^{\circ}$ and $75^{\circ} \mathrm{N}$ contribute equally to precipitation at $75^{\circ} \mathrm{N}$. Application of Peixolo and Oort's [1983] moisture fluxes shows that rather different conditions prevail in the much more maritime southern hemisphere. with polar precipitation being supplied by a less extended source region which is located farther poleward. It should be noted. however. that application of Fisher and Alt's model to the southern henisphere is somewhat suspect as their results are strongly dependent upon the prescribed moisture fluxes which are not well known over the southern oceans (section 4.1).

\section{INTRUSIONS OF WARM MOIST AIR INTO ANTARCTICA}

It is well known that cyclones rarely penetrate into East Antarctica due to the blocking effect of the elevated ice sheet [e.g.. Mechoso. 1980]. According to Facquel [1982], cloudiness associated with coastal lows frequently penetrates the continent during the summer season (October to February), but only once or twice do identifiable cyclonic centers move onto the high plateau of East Antarctica.

Facquet [1982] evaluated the upper tropospheric (400 hPa) circulation associated with vigorous poleward moisture advection for the summer seasons of 1976-1977, 1977-1978, and 1979-1980. Figure 6 gives a schematic illustration of the association between penetrating cloud masses and warm upper level ridges. By compositing the $400-\mathrm{hPa}$ anomaly height fields (observed heights minus climatological values) in relation to the most poleward extent of continuous high cloudiness associated with offshore cyclones (point $A$ in Figure 6), the characteristic circulation pattern was established. Rather than the meridional orientation sketched in Figure 6, the ridge line had a pronounced southeast to northwest tilt. The cloud sheets tended to remain over the continent for days; over half of the $\mathbf{4 0}$ cases persisted for more

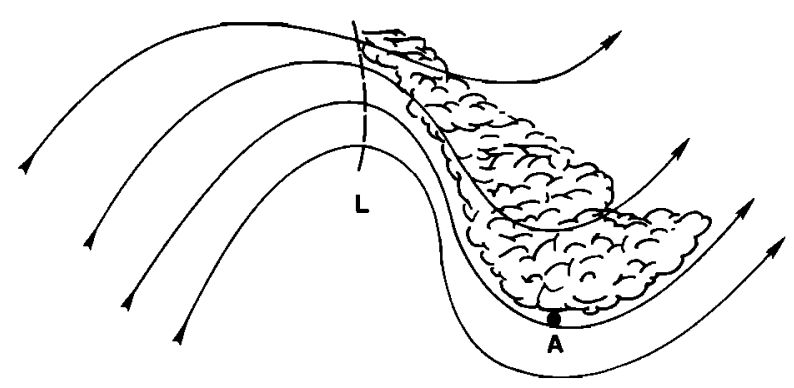

Fig. 6. Schematic illustration of the association between $400-\mathrm{hPa}$ $(=40 \mathrm{kPa})$ airflow and cloud masses which penetrate into the Antarctic interior [after Facquet, 1982]. Point $\mathrm{A}$ is located at the most poleward extent of the cloud shield and was used by Facquer [1982] as the reference location for construction of a height anomaly analysis. than 3 days, with the longest being maintained for 6 days. The case study conducted by Sinclair [1981] followed this sequence. Strong advection between offshore cyclones and ridges over the continent brought anomalously warm temperatures and precipitation to South Pole and Vostok stations in late December 1978. The event lasted for about 3 days.

The same situation applies in winter. Kodama and Wendler [1984] analyzed pressure and temperature observations from three automatic weather stations in Adelie Land deployed on an approximate north-south line from $200 \mathrm{~m}$ to $2500 \mathrm{~m}$ elevation. Between April and September 1983, above-average temperatures at all stations were associated with high and generally falling pressure readings. These results are consistent with Figure 6 if the ridges which advect warm, moist air around their western flanks typically move from west to east across the Adelie Land stations. It must also be assumed that the Antarctic atmosphere behaves in a vertically uniform (barotropic) fashion, as has been found by Rogers and van Loon [1982].

The synoptic analysis of the mid-May 1957 blizzard by Alvarez and Lieske [1960] exhibits many of the characteristics mentioned above. A warm blocking ridge extended from the South Pacific across West Antarctica at all tropospheric levels. A series of intense cyclones brought heavy snowfalls. strong winds. and high temperatures to McMurdo. Little America. and Byrd stations. located to the west of the ridge. The intensity of warm. moist advection associated with this event is illustrated by the $39^{\circ} \mathrm{C}$ temperature rise at South Pole over 4 days together with the highly unusual 26 hours of continuous light snowfall. The latitudinal extent of the advection is shown by the miniscule $1^{\circ} \mathrm{C}$ temperature difference at $700 \mathrm{hPa}$ between Byrd Station and Hobart. Tasmania: these sites are $37^{\circ}$ latitude apart and have a climatological $700-\mathrm{hPa}$ temperature contrast of $19^{\circ} \mathrm{C}$ [ Taljaard et al. . 1969].

\section{PRECIPITATION MECHANISMS}

\subsection{Coastal Regions}

From the discussion in section 4.2.1, it might be expected that precipitation over continental areas near sea level and over near-coastal ocean areas would be generated by vertical motion fields solely associated with cyclones. However, the water vapor which feeds coastal precipitation usually approaches the continent in the eastern sector of maritime lows. Sinith [1979] points out that lifting of lower tropospheric air approaching a steep. high obstacle commences well before the ground surface starts to rise. This upstream effect, as far as surface precipitation is concerned, is partly or completely offset by the downwind drift of falling precipitation particles. This means that precipitation may be occurring some distance offshore solely because of the upstream influence of Antarctic topography.

The lowest layers of poleward moving, warm, moist air masses are stabilized by the downward transport of sensible heat to the much cooler ocean (in summer) or pack ice field (in winter). Zillman [1972] and Andreas and Makshlas [1985] give examples of this phenomenon. Stably stratified air masses resist vertical motion, and under suitable circumstances their lowest layers turn and move parallel to the obstruction rather than passing over it. This damming (or blocking) effect creates low-level, mountain-parallel jets on the western slopes of the Sierra Nevada [Parish, 1982] and 


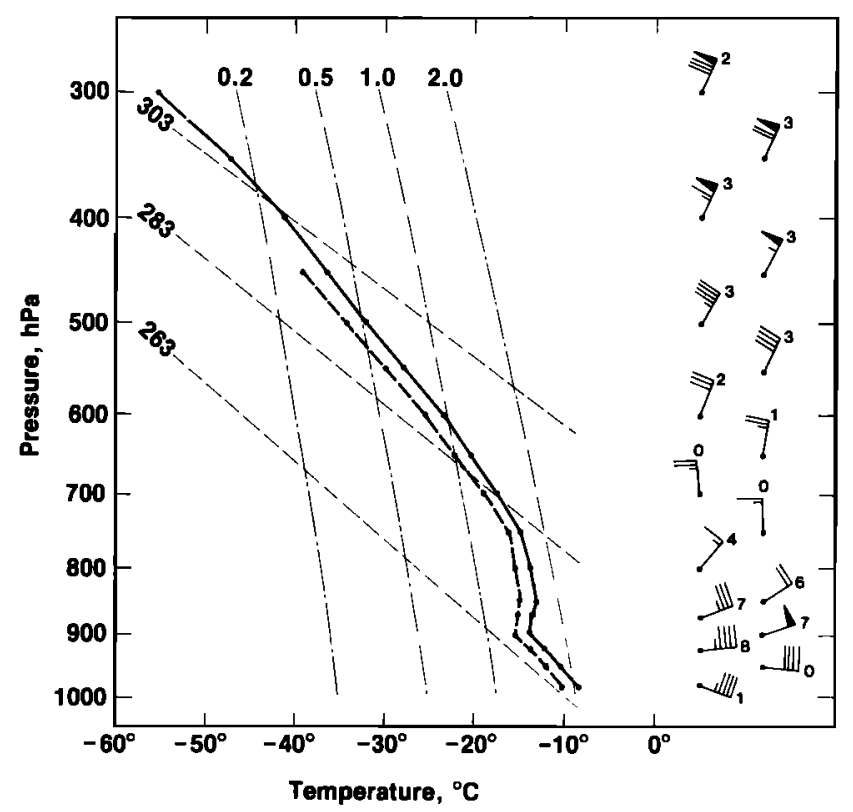

Fig. 7. Rawinsonde ascent at Mirny on 2100 UT, June 23, 1973, illustrating low-level deflection of moist air to blow parallel to the terrain. Vertical profiles of air temperature and dew point temperature are shown by heavy solid and heavy dashed lines. respectively. The sloping, light dashed lines are isentropes in kelvins, and the nearly vertical dashed lines are isopleths of saturated mixing ratio with respect to water in grams per kilogram. Horizontal wind vectors are plotted to the right. Direction is shown by orientation of wind arrows, with a northerly indicated by flow from top to bottom; wind direction rounded to the nearest $10^{\circ}$ is given by number at end of arrow. e.g. $310^{\circ} \equiv 1$ and $70^{\circ} \equiv 7$. Wind speed is shown by symbols attached to arrow; half a barb indicates $2.5 \mathrm{~m} \mathrm{~s}^{-1}$ : a full barb, $5 \mathrm{~m} \mathrm{~s}^{-1}$; and a flag. $25 \mathrm{~m} \mathrm{~s}^{-1}$.

along the eastern side of the Appalachians [Forbes et al., 1987] during winter.

Figure 7 presents an upper air sounding from Mirny during June 1973 which is interpreted to be a particularly clear case of low-level blocking. A layer of strong $\left(\geq 15 \mathrm{~m} \mathrm{~s}^{-1}\right)$ easterly winds is present in the lowest kilometer of the atmosphere, with a maximum speed of $25 \mathrm{~m} \mathrm{~s}^{-1}$ at an altitude of $700 \mathrm{~m}(900$ $\mathrm{hPa}$ ). As the terrain contours are oriented east to west, these winds are blowing approximately parallel to the coastal slopes. Between the speed maximum and $2000 \mathrm{~m}$ altitude $\mathbf{7 5 0}$ $\mathrm{hPa}$ ). the wind direction turns counterclockwise and the speed decreases. Further altitude increases yield steadily increasing speed and a nearly constant wind direction. As the $2-\mathrm{km}$ level is probably above the blocked layer, but still comparatively close to the surface, the wind at this level is presumed to represent the airflow upstream of the zone of topographic disturbance. This example is rather similar to the cases given by Parish [1982. Figure 1] where moderate flows normal to the mountain barrier generate strong mountain-parallel jets below crest height. The sounding in Figure 7 was taken during a 3-day period with strong surface winds from ESE; according to Rusin [1964]. surface winds from this direction are generated by cyclones.

Frequent low-level blocking in air masses approaching the coastal slopes has important implications for precipitation generation. Poleward moving moist air will probably follow the sloping top of the blocked layer and thus will start to rise well offshore [cf. Forbes et al., 1987]. Smith [1979] points out that the upstream topographically induced lifting which is well marked in midtroposphere but completely absent right at the surface strongly destabilizes the airstream in the absence of low-level blocking. This differential lifting can lead to convective overturning in shallow layers. Sinith [1979] reviews a wide variety of observational evidence and concludes that this previously neglected mechanism is of decisive importance for mountain precipitation in many parts of the world. When blocking occurs, the lifting contrast between surface and nidtropospheric layers is minimized. and thus convective overturning may be of secondary importance for the generation of coastal Antarctic precipitation.

Over the marginal ice slopes below the 1-km contour. the stable isotope content of firn is nearly constant: above this level, the isotope content decreases with increasing elevation. This pattern has been observed in multiannual firn samples to the south of Dumont d'Urville [Lorius and Merlival, 1977] and Mirny [Vilenskiy et al., 1978] and in drifting snow samples collected inland from Syowa Station during October 1974 [Kalo et al., 1978]. This systematic variation in isotopic values with elevation may be caused by the redistribution of deposited snow by the surface wind [Dansgaard et al., 1973] or. if drift effects are negligible, by different precipitation mechanisms for snow falling to the surface below and above $1000 \mathrm{~m}$ in elevation. The similar isotopic elevation profile of drifting snow suggests it is of local origin, which in turn implies that the isotopic profile is primarily determined by the precipitation signal.

Here it is proposed that the snow which is deposited below $1000 \mathrm{~m}$ elevation is generated by vertical motion fields associated with offshore cyclones, upstream topographic lifting, and airflow over blocked near-surface layers. Lorius and Merliva [1977] note that the base height of precipitating clouds moving southward across Dumont d'Urville is around $1000 \mathrm{~m}$. Snow formed in these clouds under similar condensation conditions would have approximately constant isotopic values. Once these clouds intersect the rising terrain. direct orographic lifting probably dominates precipitation formation. leading to the observed isotopic decrease with increasing elevation.

Pettre et al. [1987] have studied the annual accumulation profile to the south of Dumont d'Urville. Between -900 and $2300 \mathrm{~m}$ elevation, five distinct accumulation maxima and minima were found with a spatial wavelength of about $40 \mathrm{~km}$ along the fall line. They speculate that this cyclic pattern is caused by a standing wave in the atmospheric boundary layer which locally enhances and suppresses the orographic snowfall. Such a situation probably requires that most of the water vapor contributing to local snowfall follows the top of the boundary layer and that wave crests and troughs coincide with substantial departures from the overall mean boundary layer deptll. Analyses dealing with the wind and accumulation variations along the terrain contours are needed to substantiate this hypothesis.

\subsection{East Antarctic Plateau}

A renuarkable characteristic of the precipitation regime near the ice sheet crest is the scarcity of regular snowfall from clouds. Snowfall is observed only $2 \%$ of the time at Plateau and Vostok stations [Schwerdtfeger, 1984, p. 194]. Kuhn [1970] reports that most (87\% according to Radok and Lile 
TABLE 6. Main Types of Ice Crystals Observed at Plateau Station in 1967 [Kuhn, 1970]

\begin{tabular}{|c|c|c|c|}
\hline Crystal Type & Size & $\begin{array}{l}\text { Formation } \\
\text { Temperature }\end{array}$ & Comments \\
\hline $\begin{array}{l}\text { Prismatic columns } \\
\text { and bullets } \\
\text { (capped columns) }\end{array}$ & $\begin{array}{l}\text { Bullets }{ }^{* *} \text { and columns: } \\
\text { length } 0.5-1 \mathrm{~mm} \text {, } \\
\text { width } 0.1-0.3 \mathrm{~mm}\end{array}$ & $<-20^{\circ} \mathrm{C}$ & $\begin{array}{l}\text { Constituted bulk of precipitation. Both } \\
\text { columns and bullets contained air pockets } \\
\text { and other irregularities that became more } \\
\text { prominent as temperature fell. Produced } \\
\text { optical phenomena. }\end{array}$ \\
\hline $\begin{array}{l}\text { Compound forms of } \\
\text { columns and bullets }\end{array}$ & As above & $<-30^{\circ} \mathrm{C}$ & As above. \\
\hline Whiskers & $\begin{array}{l}\sim 0.1 \mathrm{~mm} \text { long, } \\
-0.01 \mathrm{~mm} \text { diameter }\end{array}$ & -40 to $-60^{\circ} \mathrm{C}^{\dagger}$ & $\begin{array}{l}\text { Noted infrequently (on } 38 \text { days in } \\
1967^{\dagger} \text { ) mostly before and after } \\
\text { synoptic scale disturbances. Produced } \\
\text { "fluffy" (density } 0.01 \mathrm{~g} \mathrm{~cm}^{-3} \text { ) but } \\
\text { coherent surface layer which formed } \\
2-5 \mathrm{~cm} \text { diameter balls when blown off } \\
\text { obstacles and across the surface by } \\
\text { the wind. Found to accumulate only } \\
\text { on the lower half of the } 32-\mathrm{m} \text { meteoro- } \\
\text { logical tower }{ }^{\dagger} \text {. Did not produce halos. }\end{array}$ \\
\hline $\begin{array}{l}\text { Granular snow } \\
\text { crystals }\end{array}$ & $\begin{array}{l}0.5-1 \mathrm{~mm} \text { in } \\
\text { diameter }\end{array}$ & $\begin{array}{l}\mathrm{N} / \mathrm{C}^{\ddagger} \text {, but prob- } \\
\text { ably only during } \\
\text { summer }\end{array}$ & $\begin{array}{l}\text { Formed from dendrites by accretion of } \\
\text { water droplets associated with low } \\
\text { clouds. Did not produce halos. }\end{array}$ \\
\hline Stellar dendrites & $\leq 2 \mathrm{~mm}$ & $\geq-20^{\circ} \mathrm{C}$ & $\begin{array}{l}\text { Observed only three times in } 1967 . \\
\text { Produced halos. Only during summer. }\end{array}$ \\
\hline Hexagonal plates & $\mathrm{N} / \mathrm{C}$ & $\geq-22^{\circ} \mathrm{C}$ & $\begin{array}{l}\text { Noted occasionally during summer. } \\
\text { Produced halos. }\end{array}$ \\
\hline
\end{tabular}

\footnotetext{
- Highest surface air temperature recorded was $-18.5^{\circ} \mathrm{C}$ [Schwerdtfeger, 1970]. * From Miller [1974].

t From Kuln [1979].

\$/C means no information given by Kuhn [1970].
}

[1977]) of the 1967 precipitation total at Plateau consisted of ice prisms falling from clear skies or from clouds. Annually, ice crystal precipitation occurs on 316 days at Plateau [Schwerdtfeger, 1970] and 247 days at Vostok [Schwerdtfeger, 1984]. Precipitation intensity at Plateau ranged from intermittent falls of single crystals to heavy, continuous ice crystal precipitation which reduced atmospheric transparency by $8 \%$ [Kuhn, 1970].

Three sources of precipitated ice crystals at Plateau Station are identified by $K u / h n$ [1970]. The principal origin is formation from advected moisture under clear skies. Another source, during the summer half-year, is vapor that sublimates from the surface during the day and that precipitates at night. Crystals start to fall around midnight and continue to fall for 6 to 12 hours. The third source is ice particles from cirrus clouds which either fall straight to the surface or sublimate and then reform in the inversion layer. The first two sources constitute the so-called "clear sky precipitation." The main ice crystal types are summarized in Table 6.

Miller [1974] conducted a theoretical analysis of the steady state moisture budget of the isothermal layer over the Antarctic plateau during the colder part of the year. This is the warmest tropospheric region and, as a consequence of the exponential dependence upon temperature of the moisture- holding capacity of the air (Clausius-Clapeyron equation), contains much more water vapor than the cold near-surface layers. For example. if ice saturation is assumed, then during average winter conditions at Vostok [Schwerdifeger. 1970]. air at the top of the surface inversion holds 21 times more moisture than that at the surface. The base of the isothermal layer lies several hundred meters above the surface, and the depth is 500 to $1000 \mathrm{~m}$. By comparing the growth rate with fall speed of the dominant ice crystal types at Plateau (columns and bullets (Table 6)), it was inferred that these crystals must grow in the isothermal layer at supersaturations with respect to ice of 20-30\%. By contrast. whiskers can grow within the inversion layer.

The annual ice crystal precipitation for the plateau above $3000 \mathrm{~m}$ elevation was estimated by Miller [1974] to be $14 \mathrm{~kg}$ $\mathrm{m}^{-2}$. This was obtained by assuming ice-saturated air in the steady state isothermal layer moves isobarically over the interior with $\mathrm{a}+3^{\circ} \mathrm{C} \mathrm{d}^{-1}$ warm advection being entirely balanced by radiative cooling. A scale analysis readily shows for slopes of $10^{-3}$ during quiescent periods that radiative cooling is much larger than cooling due to orographic lifting. The assumed advection was the winter average (April-October) geostrophic value measured in the warmest layer $(600-650 \mathrm{hPa}$, 400-900 $\mathrm{m}$ altitude) above South Pole Station. The assumed heat balance was presumed to persist for 300 days per year, 
TABLE 7. Types and Formation Conditions of Ice Crystals Observed at South Pole [Ohrake and liouc, 1980]

\begin{tabular}{|c|c|c|c|}
\hline Crystal Classification & Size & Formation Conditions & Comments \\
\hline Assembled bullets & $\begin{array}{l}1 \mathrm{~mm} \text { or } \\
\text { larger }\end{array}$ & $\begin{array}{l}\text { Associated with influx of moist } \\
\text { air at } 500 \text {-hPa level }(\sim 2300 \mathrm{~m} \\
\text { altifude }) \text { in summer and } 600 \mathrm{hPa} \\
(\sim 850 \mathrm{~m} \text { altitude }) \text { in winter at } \\
\text { temperatures of }-40^{\circ} \text { to }-55^{\circ} \mathrm{C} \text {. } \\
\text { Often occurs with cirrus or cir- } \\
\text { rostratus clouds at altitudes of } \\
2000 \text { to } 4500 \mathrm{~m} \text {. }\end{array}$ & $\begin{array}{l}\text { Most common and largest } \\
\text { crystal type in winter } \\
\text { and summer. Major con- } \\
\text { tributor to annual } \\
\text { accumulation. }\end{array}$ \\
\hline $\begin{array}{l}\text { Compound crystals in } \\
\text { form of side planes. } \\
\text { bullets and columns }\end{array}$ & $-1 \mathrm{~mm}$ & $\begin{array}{l}\text { Associated with moist air at } \\
670-\mathrm{hPa} \text { level }(-150 \mathrm{~m} \text { altitude } \\
\text { at temperatures of }-35^{\circ} \text { to }-45^{\circ} \mathrm{C} \text {. } \\
\text { Occurs with broken or overcast } \\
\text { altostratus or altocumulus } \\
\text { clouds between } 300 \text { and } 1000 \mathrm{~m} \\
\text { altitude. }\end{array}$ & $\begin{array}{l}\text { Infrequent occurrence. } \\
\text { Smaller contributor to } \\
\text { annual accumulation } \\
\text { than assembled bullets. }\end{array}$ \\
\hline $\begin{array}{l}\text { Thin hexagonal plates } \\
\text { and columns smaller } \\
\text { than } 0.2 \mathrm{~mm}\end{array}$ & $<0.2 \mathrm{~mm}$ & $\begin{array}{l}\text { Created in first } 1000 \mathrm{~m} \text { above } \\
\text { the surface at temperatures } \\
\text { lower than }-25^{\circ} \mathrm{C} \text { with light } \\
\text { northerly surface winds. } \\
\text { Usually occur in the absence } \\
\text { of visible cloud, but some- } \\
\text { times in conjunction with } \\
\text { fractostratus (liquid water } \\
\text { cloud) in summer. }\end{array}$ & $\begin{array}{l}\text { Dominant component of } \\
\text { clear sky precipitation. } \\
\text { Do not contribute sub- } \\
\text { stantially to annual } \\
\text { accumulation. }\end{array}$ \\
\hline $\begin{array}{l}\text { Pencil and triangular- } \\
\text { shaped crystals }\end{array}$ & $\begin{array}{l}\text { Pencil: } \\
\text { length } \\
<0.6 \mathrm{~mm}(?) \text {, } \\
\text { width } \leq 0.5 \% \\
\text { of length. } \\
\text { Triangle } \\
-0.1 \mathrm{~mm} \text {. }\end{array}$ & $\begin{array}{l}\text { Formed near the surface under } \\
\text { clear skies with light north- } \\
\text { easterly surface winds and } \\
\text { temperatures lower than } \\
-49^{\circ} \mathrm{C} \text {. Lack of identifiable } \\
\text { nuclei implies homogeneous } \\
\text { nucleation at temperatures } \\
\text { colder than }-40^{\circ} \mathrm{C} \text {. }\end{array}$ & $\begin{array}{l}\text { Component of clear sky } \\
\text { precipitation. Do not } \\
\text { contribute significantly } \\
\text { to annual accumulation.* }\end{array}$ \\
\hline $\begin{array}{l}\text { Block and polyhedral } \\
\text { crystals }\end{array}$ & $-0.02 \mathrm{~mm}$ & $\begin{array}{l}\text { Formed in winter with cloudless } \\
\text { skies at temperatures of }--58^{\circ} \mathrm{C} \text {. } \\
\text { Polyhedral crystals inferred to } \\
\text { have formed under conditions } \\
\text { supersaturated relative to waler } \\
\text { [Ohrah' and Yoyt. 1979]. }\end{array}$ & $\begin{array}{l}\text { Component of clear sky } \\
\text { precipitation. Do not } \\
\text { contribute significantly } \\
\text { to annual accumulation." }\end{array}$ \\
\hline
\end{tabular}

*Material added by present author.

and the warm advection layer was taken to be $1000 \mathrm{~m}$ thick. As pointed out by Schwerdifeger [1984, p. 194], the neglect of short periods of strong warm advection (in which orographic lifting probably plays a significant role) means that the above estimate is on the low side. As the annual accumulation (i.e., precipitation) for elevations above $3000 \mathrm{~m}$ is about 30 $\mathrm{kg} \mathrm{m}^{-2}$ (Figure 2), it can be inferred that ice crystal fall is the dominant component of the precipitation regime.

A number of studies conducted at South Pole Station have substantially clarified the nature of precipitation processes in the Antarctic interior. In particular, Lax and Schwerdffeger [1976] have shown that $84 \%$ of summer days (December and January) with precipitation (mostly ice crystals) occur when air in the warmest layer $(650-600 \mathrm{hPa})$, which is supersaturated with respect to ice. comes from the direction of lower elevations. This means that summer precipitation is predominantly produced by orographic lifting of moist air. Locally downward motion of saturated air, on the other hand. decreases the likelihood of precipitation particle formation or survival. These summer findings have been substantiated by Inoue et al. [1984] and Olirake and Inoue [1980]. Smiley et al. [1980] have shown that 1975 winter clear sky precipitation events were associated with predominantly upslope winds in the 650 to $600-\mathrm{hPa}$ layer; $400-\mathrm{hPa}$ winds showed no directional organization however.

Ohtake and houre [1980] summarize extensive summer and winter observations of ice crystal precipitation at South Pole. They classified the crystals into five categories, which are listed in Table 7 . The annual precipitation total is, in contrast to the Plateau situation, found to be mostly associated with clouds. Small crystals may be falling out of cloud layers and growing in underlying moist layers [Kuhn, 1970: Hogan, 1975]. The resulting winter formation level (600 $\mathrm{hPa}$ ) for the predominant ice crystal type (assembled bullets) is close to the level of precipitation formation inferred from winter isotopic measurements [Bromivich, 1982. Table 3]. Bullets seen to be more common at South Pole than at Plateau, while the reverse applies to columns. Whiskers (Table 6) and pencil-shaped ice crystals (Table 7) are very likely to be the same crystal form.

Smiley et al. [1980] used lidar measurements and ice crystal replicas to study 1975 winter clear sky precipitation at South Pole. In $75 \%$ of the analyzed events, a low-lying growth layer and a higher initiation layer were resolved by 
the lidar data. The average altitude of the growth layer was just below (during the polar night) and just above (during the polar day) the top of the surface temperature inversion (the warmest tropospheric level at $\sim 540 \mathrm{~m}$ altitude). This approximately corresponds to Miller's [1974] isothermal layer. Smiley ef al. [1980] suggest that clear sky precipitation is frequently initiated by small crystals falling out of the initiation layer where they arise by homogeneous nucleation. These crystals then grow in the warmer ice-supersaturated environment of the growth layer. It thus appears that the same precipitation processes take place regardless of whether or not there is visible cloud in the initiation layer. The principal ice crystal types were plates. prisms, bullets. and clusters of crystals with sizes between 0.08 and $0.2 \mathrm{~mm}$; these results approximately concur with those in Table 7 .

lnolve et al. [1984] investigated summer clear sky precipitation occurrences at South Pole. This was found to be a short-tern transition phenomenon between clear skies without precipitation and precipitation from clouds. Careful evaluation of upper air humidity measurements revealed thin layers close to the surface which were supersaturated with respect to ice; as a result, the condensed ice particles were too few in number to be visible as a cloud. Apart from the short duration, characteristics of precipitation from such layers were similar to those from stratiform clouds. By analogy with Arctic ice crystal formation [Ohtake et al., 1982], Ohrake and Inoue [1980] suggest that clear sky precipitation particles at South Pole may form from stratus cloud droplets by freezing: notice that Miller [1974] adopted the more likely assumption that ice crystals grow by diffusion. Stratus clouds, which are presumably below the horizon much of the time. form as moist air rises up the terrain toward South Pole. The smallsized particles may have a slow enough fall speed to be consistent with precipitation from clouds beyond the horizon.

The preceding discussion indicates that at South Pole, precipitation from both clouds and clear skies is primarily generated by the same mechanism, namely. the orographic lifting of moist air. The moist air is probably advected over South Pole by baroclinic eddies circling the continent [Schwerdifeger, 1970, Figure 15]. The principal difference between these two precipitation situations is the quantity of atmospheric vapor which is supersaturated relative to ice [holve ef al., 1984]. This contrast is embodied in the quantity called precipitable ice by Inoue et al. [1984]:

$$
\begin{array}{ll}
w_{i c e}=\int_{0}^{P}\left\{\left(q-q_{i}\right) / g\right\} d p & q \geq q_{i} \\
w_{\text {ice }}=0 & q<q_{i}
\end{array}
$$

where $q_{i}$ is the saturated specific humidity relative to ice. $W_{i c e}$ is large when precipitation comes from clouds but snall when precipitation falls from clear skies.

Because the amount of atmospheric water vapor (W) decreases with increasing elevation [Burova and Voskresenskiy, 1975], it is probable that clear sky precipitation contributes an increasing fraction of the annual total at progressively higher elevations. Radiative cooling is the dominant mechanism by which supersaturation relative to ice is maintained in precipitating air masses over the highest parts of the ice sheet.

\section{SUMMARY AND CONCLUSIONS}

Significant progress has recently been made in techniques to directly and indirectly determine Antarctic precipitation amounts. Measurements of the horizontal transport of falling snow particles either above or within the layer of blowing snow may allow precipitation to be monitored at sites subject to strong, persistent katabatic winds. Precipitation estimates obtained as residuals from the atmospheric water balance equation are reliable for seasonal time scales and for areas of at least $10^{6} \mathrm{~km}^{2}$, provided the dominant atmospheric vapor fluxes are well resolved. This approach could be used to study interannual precipitation variations over East Antarctica.

Several lines of evidence demonstrate that the majority of Antarctic precipitation falls during the winter, when the average atmospheric moisture content is low. This, in conjunction with the zonally averaged dominance of the transient eddy moisture fluxes, means that the intensity of cyclonic activity is the key aspect of precipitation generation. Realistic attempts to simulate precipitation amounts for different climatic conditions (e.g., during the Wisconsinan glacial period) must be based upon an accurate assessment of atmospheric behavior at that time.

Comparison of the annual cycles of precipitation and accumulation at Mizuho Station illustrates the limitations in using the latter for precipitation investigations at sites with strong katabatic winds. Precipitation rates are high during winter and least in summer. The composite of 5 years of accumulation measurements shows a strong peak in February and March but generally low values for the remainder of the year [Fujii and Ohata, 1982]. The discrepancy can probably be attributed to wind removal of most of the winter precipitation.

Topographically forced moisture transport convergence is responsible for the meridional precipitation distribution in the Antarctic. with large amounts over the marginal ice slopes and small values in the continental interior. Variations in amounts of zonal precipitation are linked with the quasistationary cyclones in the circumpolar low-pressure trough and ultimately to the positions of the long waves in the hemispheric circulation. Penetrations far into the continent of warm moist air masses with their abundant precipitation are associated with marked southerly winds through a deep tropospheric layer. This suggests that circulation diagnostics calculated for the 500-lıPa level (one of the primary analysis levels for the southern hemisphere) can be used to infer a large fraction of Antarctic precipitation variability [cf. Klein and Bloom. 1987/.

It has been shown that the lowest layers of poleward moving air masses over the southern oceans are probably deflected to blow westward parallel to the marginal ice slopes. This profoundly influences the generation of precipitation over ice slopes below $1000 \mathrm{~m}$ elevation. This boundary layer blocking also intensifies the circumpolar easterlies. Direct orographic lifting of moist air is the dominant precipitation formation mechanism farther inland.

Over the highest parts of the ice sheet (above the 3-km contour), radiative cooling is generally more important than orographic lifting for precipitation formation. As the elevation increases. clear sky precipitation contributes a progressively larger fraction of the annual precipitation total. This phenomenon does not differ from cloud precipitation but results from the low absolute amount of water vapor at these altitudes. Thus, the layer of ice particles is just too thin to be viewed as a cloud.

Finally, it should be noted that the results summarized above are in general agreement with the Antarctic precipi- 
tation parameterization scheme used by Oerlemans [1982] in ice sheet modeling studies. The present precipitation (equated with accumulation) distribution was represented by

$$
\overline{\mathbf{P}}=920\left(0.3+14 \mathrm{~S}-4 \times 10^{-5} \mathrm{~h}\right) / \mathrm{C} \mathrm{mm} \mathrm{yr}^{-1}
$$

where $S$ is the slope of the ice sheet. $h$ the surface elevation in meters, and $\mathrm{C}$ a continentality factor which ranges from $\mathbf{1 . 5}$ at the coast to 2 in the interior of the continent. $\overline{\mathbf{P}}$ was required to be no smaller than $46 \mathrm{~mm} \mathrm{yr}^{-1}$. Over the marginal ice slopes, the slope term is large and the elevation term is negligible. This models the near-coastal predominance of orographic precipitation formation but does not resolve the effects of low-level blocking of moist air below $1000 \mathrm{~m}$ elevation. For the high interior where slopes are $\sim 10^{-3}$, the slope term is negligible and the elevation term is large. This represents precipitation formation far from the coast $(C=2)$ where the amount of precipitable water is low, i.e., similar to the crest area where clear sky precipitation predominates. The modeled precipitation pattern for East Antarctica is qualitatively correct, with (8) producing large values near the coast and small values in the interior. However. the precipitation amounts modeled for elevations above $3000 \mathrm{~m}$ appear to be almost twice as large as those given in Figure 2. For West Antarctica, simulated precipitation amounts over the ice slopes facing the Bellingshausen Sea are only about $50 \%$ of those observed. Satellite studies [Streten and Troup. 1973; Carleton, 1981] show a high year-round frequency of dissipating vortices in this sector. The reasonable overall fit between parameterized and observed precipitation distributions for coastal parts of East Antarctica. where longitudinal averages of poleward moisture transports are fairly constant (section 4.2.1), suggests that the Bellingshausen Sea region is characterized by much larger poleward moisture transports. The preceding discussion indicates that equation (8) could be adapted to represent most of the gross features in Figure 2.

Acknowledgments. The original work reported here was supported by National Science Foundation grants DPP-8100142 and DPP-7704506. C. R. Bentley provided copies of original diagrams which were used to construct Figure 2. A. J. Gow, A. Hogan, E. Mosley-Thompson, and I. M. Whillans took time from their busy schedules to review the manuscript. Suggestions from two anonymous reviewers also improved the article. All this assistance is gratefully acknowledged. Contribution 605 of Byrd Polar Research Center, The Ohio State University.

\section{REFERENCES}

Alvarez, J. A., and B. J. Lieske, The Little America blizzard of May 1957, in Aniarctic Meleorology. Proceedings of the Symposium, Melbourne, 1959, pp. 115-127, Pergamon, New York, 1960.

Andreas, E. L., and A. P. Makshtas, Energy exchange over Antarctic sea ice in the spring, J. Geophys. Res., 90, 7199$7212,1985$.

Astapenko, P. D., Almospheric Processes in the High Latitudes of the Southern Hemisphere, translated from Russian, Israel Program for Scientific Translations. Jerusalem, 1964.

Atlas of Antarctica, Vol. 1, GUGK, Moscow, 1966.

Australian National Antarctic Research Expeditions, Meleorology: Macquarie Island, Mawson and Wilkes, 1965. ANARE Dala Reports, Series D (XVIII) Meteorology, Publ. 98, Antarctic Division, Melbourne, 1968.
Australian National Antarctic Research Expeditions, Meteoralogy: Macquarie Island, Mawson and Wilkes, 1966, ANARE Data Reporls, Series D (XIX) Meteorology, Publ. 109, Antarctic Division, Melbourne, 1969.

Australian National Antarctic Research Expeditions. Meteorology: Macquarie Island. Mawson and Wilkes, 1967. ANARE Data Reports, Series D (XX) Meleorology, Publ. 113, Antarctic Division. Melbourne, 1970.

Barkov, N. I., Snow accumulation along the profile MirnyVostok in the years 1970-1973 (in Russian), in Data of Glaciological Studies, Chronicle, Discussion, vol, 24, pp. 255-257. Academy of Sciences USSR. Moscow, 1974.

Baumgartner, A., and E. Reichel, The World Waler Balance, Elsevier, New York, 1975.

Bradley, R. S., H. F. Diaz, J. K. Eischeid. P. D. Jones, P. M. Kelly, and C. M. Goodess, Precipitation fluctuations over northern hemisphere land areas since the mid-19th century, Science, 237, 171-175, 1987.

Bromwich. D. H., Some considerations in deriving poleward water vapor transport values for coastal East Antarctica, Antarct. J. U.S. I3(4), 196-197, 1978.

Bromwich. D. H.. Precipitation and accumulation estimates for East Antarctica, derived from rawinsonde information. research report. Dep. of Meteorol. Univ. of Wisconsin. Madison. 1979.

Bromwich. D. H., Intra-annual relationships between oxygenisotopic composition of precipitation and temperature at the south pole. Anlarct. J. U.S., I7(5), 85-87. 1982.

Bromwich, D. H.. Precipitation regime of the West Antarctic ice sheet, in Environment of West Antarctica: Potential $\mathrm{CO}_{2}$-Induced Changes. pp. 107-1 15, National Academy Press, Washington, D.C., 1984.

Bromwich. D. H., and C. J. Weaver. Latitudinal displacement from main moisture source controls $\delta^{18} \mathrm{O}$ of snow in coastal Antarctica, Nalure, 301, 145-147, 1983.

Brooks. C. E. P.. The secular variation of rainfall, $Q . J . R$. Meteorol. Soc., 45, 233-248, 1919.

Bryan. F., and A. Oort. Seasonal variation of the global water balance based on aerological data. J. Geophys. Res., 89. $11,717-11.730,1984$.

Bryazgin, N. N., Atmospheric precipitation in Antarctica, Polar Geogr. Geol., 6, 210-218, 1982.

Bryazgin, N. N., Method of preparing monthly charts of atmospheric precipitation in Antarctica, in Climate of Antarctica, edited by I.M. Dolgin, pp. 109-116, Oxonian, New Delhi, 1986.

Bull, C.. Snow accumulation in Antarctica, in Research in the Anlarcic, Publ. 93, edited by L.O. Quam. pp. 367-421. American Association for the Advancement of Science, Washington, D.C., 1971.

Burova, L. P., and A. I. Voskresenskiy, Estimation of the components of moisture exchange in Antarctica, Sov. Anlarct. Exped. Inf. Bull., Engl. Transl., 90, 643-646. 1975.

Carleton, A. M., Ice-ocean-atmosphere interactions at high southern latitudes in winter from satellite observation, Aust. Mcicorol. Mag., 29, 183-195, 1981.

Chen, T.-C., Global water vapor flux and maintenance during FGGE, Mon. Weather Rev., I13, 1801-1819, 1985.

Dansgaard, W., Stable isotopes in precipitation, Tellus, 16 , 436-468, 1964.

Dansgaard, W., S. J. Johnsen, H. B. Clausen. and N. Gundestrup, Stable isotope glaciology, Medd. Groenl., 197(2). 1-53, 1973. 
Dolgina, I. M.. and L. S. Petrova (Eds.), Handbook of Antarctic Climale (in Russian), Vol. 2, Gidrometeorzdat, Leningrad, 1977.

Drewry, D. J., The surface of the Antarctic ice sheet, in Antarctica: Glaciological and Geophysical Folio, edited by D.J. Drewry, Sheet 2, Scott Polar Research Institute, Cambridge, England. 1983.

Facquet, R. L., A synoptic/statistical analysis of summer season circulation patterns over eastern Antarctica during moist air intrusions. M.S. thesis, Naval Postgraduate School. Monterey, Calif., 1982.

Fisher, D. A., and B. T. Alt, A global oxygen isotope model semi-empirical. zonally averaged, Ann. Glaciol., 7. 117-124. 1985.

Forbes. G. S.. R. A. Anthes, and D.W. Thomson. Synoptic and mesoscale aspects of an Appalachian ice storm associated with cold-air damming. Mont. Weather R'v., 1/5, 564-591. 1987.

Fujii. Y., and K. Kusunoki. The role of sublimation and condensation in the formation of the ice sheet surface at Mizuho Station. Antarctica. J. Giophys. R's., 87, 4293-4300, 1982.

Fujii. Y., and T. Ohata. Possible causes of the variation in microparticle concentration in an ice core from Mizuho Station. Antarctica. Ann. Glaciol., 3, 107-112. 1982.

Giovinetto. M. B., The drainage systems of Antarctica: Accumulation, in Antarctic Snow and Ice Studies, Antarct. Res. Ser., vol. 2, edited by M. Mellor, pp. 127-155, AGU, Washington, D.C., 1964.

Giovinetto. M. B., and C. R. Bentley. Surface balance in ice drainage systems of Antarctica, Amarct. J. U.S., 20(4), 6-13, 1985.

Giovinetto, M. B., and C. Bull, Summary and analyses of surface mass balance compilations for Antarctica, 1960-1985, Rep. I, Byrd Polar Research Center, Ohio State University, Columbus, 1987.

Giovinetto, M. B.. and W. Schwerdtfeger, Analysis of a 200year snow accumulation series from. the south pole, Arch. Meteorol. Geophys. Bioklimatol., Ser. A, 15, 227-250, 1966.

Hogan, A. W., Summer ice crystal precipitation at the south pole. J. Appl. Meleorol., 14, 246-249, 1975.

Howarth. D. A., Seasonal variations in the vertically integrated water vapor transport fields over the southern hemisphere. Mon. Wealher Rev., 111, 1259-1272, 1983.

Howarth. D. A.. and J. N. Rayner, Estimates of sources and sinks of atmospheric moisture in the southern hemisphere, in Second International Conference on Southern Henisphere Metcorology, pp. 163-166, American Meteorological Society, Boston. Mass.. 1986.

Inoue, M., T. Ohtake, and G. Wakahama, Summer precipitation onto the south polar plateau. Mem. Nall. Inst. Polar Res. Spec. Issue Jpn., 34. 70-86, 1984.

Jenne, R. L., H. L. Crutcher, H. van Loon, and J. J. Taljaard, Climate of the upper air: southern hemisphere, vol. 3, Vector mean geostrophic winds, rep. NCAR-TN/STR-58, National Center for Atmospheric Research, Boulder. Colo., 1971.

Jouzel, J., L. Merlivat, J. R. Petit, and C. Lorius, Climatic information over the last century deduced from a detailed isotopic record in the south pole snow, J. Geophys. Res., 88, 2693-2703, 1983.

Karoly. D. J., and A. H. Oort, Southern hemisphere circulation statistics for water vapor from GFDL and Australian analyses, in Second International Conference on Southern.
Hemisphere Meteorology, pp. 269-271, American Meteorological Society, Boston, Mass., 1986.

Kato, K.. Factors controlling oxygen isotopic composition of fallen snow in Antarctica, Nature, 272, 46-48, 1978.

Kato, K. . O. Watanabe, and K. Satow, Oxygen isotopic composition of the surface snow in Mizuho Plateau. in Mein. Natl. Inst. Polar Re's. Spec. Issue Jpn., 7, 245-254. 1978.

Kellogg, W. W., Climatic feedback mechanisms involving the polar regions. in Climate of the Arctic, pp. 111-116. Geophysical Institute. University of Alaska. Fairbanks. 1975.

Klein, W. H., and H. J. Bloom. Specification of monthly precipitation over the United States from the surrounding $700 \mathrm{mb}$ height field. Mon. Wealher Rev., 115. 2118-2132. 1987.

Kobayashi, S.. Annual precipitation estimated by blowing snow observations at Mizuho Station. East Antarctica. 1980. in Proceedings of Scventh Symposium on Polar Metcorology and Glaciology. edited by S. Kawaguchi, pp. 117-122. National Institute of Polar Research, Tokyo, 1985.

Kobayashi, S., N. Ishikawa, and T. Ohata, Katabatic snow storms in stable atmospheric conditions at Mizuho Station, Antarctica, Ann. Glaciol., 6, 229-231, 1985.

Kodama, Y., and G. Wendler, Coreless winter in Adelie Land, Antarctica, in 1983, Antarct. J. U.S., 19(5), 199-201, 1984.

Kotlyakov, V. M., and V. Y. Sharova, Amount of precipitation (in Russian), in Allas of Antarctica, Vol. 2, pp. 328-332, Gidrometeorzdat, Leningrad, 1969.

Kuhn, M., Ice crystals and solar halo displays, Plateau Station, 1967, IAHS Publ., 86, 298-303, 1970.

Kuhn, M., Precipitation of whisker crystals at surface temperatures below $-60^{\circ} \mathrm{C}$ on the East Antarctic plateau, in Collecrion of Contributions Presented at CPM Sessions, IAGA/lAMAP Assembly, Seattlc, Washington, September, 1977. edited by M. Kuhn, pp. 60-65, National Center for Atmospheric Research, Boulder, Colo.. 1979.

Lax, J. N., and W. Schwerdtfeger, Terrain-induced vertical motion and occurrence of ice crystal fall at South Pole in summer, Antarct. J. U.S., 9, 144-145, 1976.

Lettau, B., The transport of moisture into the Antarctic interior, Tellus, 2l(3), 331-340, 1969.

Limbert, D. W. S., West Antarctic temperatures, regional differences, and the nominal length of summer and winter seasons, in Environment of West Antarctica: Potential $\mathrm{CO}_{2}$-Induced Changes, pp. 116-139. National Academy Press, Washington, D.C., 1984.

Loewe, F., Precipitation and evaporation in the Antarctic. in Meteorology of the Antarctic, edited by M.P. van Rooy, pp. 71-89, Weather Bureau. Pretoria, South Africa, 1957.

Loewe, F., The transport of snow on ice sheets by the wind, in Studies on Driffing Snow, Publ.13. Meteorology Department, University of Melbourne, Melbourne. Australia, 1970.

Lorius, C., Accumulation rate measurements on cold polar glaciers, in The Climatic Record in Polar Ice Sheets, edited by $\mathrm{G}$. de Q. Robin, pp. 65-70. Cambridge University Press, New York, 1983.

Lorius, C. . and L. Merlivat, Distribution of mean surface stable isotope values in East Antarctica: Observed changes with depth in the coastal area. IAHS Publ.. I/8, 127-137. 1977.

Mechoso, C. R., The atmospheric circulation around Antarctica: Linear stability and finite amplitude interactions with migrating cyclones, J. Amos. Sci., 37. 1224-1248, 1980. 
Miller, S. A., An analysis of heat and moisture budgets of the inversion layer over the Antarctic plateau. for steady state conditions, researcl report. Dep. of Meteorol., Univ. of Wisconsin. Madison, 1974.

Mosley-Thompson. E.. and L. G. Thompson. Nine centuries of microparticle deposition at the south pole, Quat. Res. N.Y., 17. 1-13, 1982.

Muszynski. I., and G. E. Birchfield. The dependence of Antarctic accumulation rates on surface temperature and elevation. Tellus, Ser. A, 37. 204-208. 1985.

Oerlemans. J., Effect of irregular fluctuations in Antarctic precipitation on global sea level. Nature. 290. 770-772. 1981.

Oerlemans. J.. Response of the Antarctic ice sheet to a climatic warming: A model study. J. Climatol., 2, 1-11, 1982.

Ohtake, $T$., and $M$. Inoue, Formation mechanism of ice crystal precipitation in the Antarctic atmosphere, in Proceedings of $8 \mathrm{th}$ International Conference on Cloud Physics, pp. 221-224, Laboratoire Associe de Meteorologie Phys..Univ. of Clermont-Ferrand. Clermont-Ferrand. France. 1980.

Ohtake, T., and T. Yogi, Winter ice crystals at South Pole, Antarct. J. U.S., 14(5), 201-203, 1979.

Ohtake, T., K. Jayaweera, and K. Sakurai, Observation of ice crystal formation in lower Arctic atmosphere, J. Almos. Sci., 39, 2898-2904, 1982.

Parish, T. R., Barrier winds along the Sierra Nevada Mountains, J. Appl. Metcorol., 21, 925-930, 1982.

Parish, T. R., and D. H. Bromwich, The inversion wind pattern over West Antarctica. Mon. Weather Rev., 1/4, 849-860, 1986.

Parish, T. R., and D. H. Bromwich, The surface windfield over the Antarctic ice sheets. Nature, 328, 51-54, 1987.

Peixoto, J. P. and A. H. Oort, The atmospheric branch of the hydrological cycle and climate, in Variations in the Global Water Budget, edited by A. Street-Perrott. M. Beran, and R. Ratcliffe. pp. 5-65. D. Reidel, Hingham. Mass., 1983.

Pettre, P.. J. F. Pinglot, M. Pourchet, and L. Reynaud, Accumulation distribution in Terre Adelie, Antarctica: Effect of meteorological parameters. J. Glaciol., 32. 486-500, 1987.

Polar Research Board. Glaciers, Ice Sheets and Sea Level: Effect of a $\mathrm{CO}_{2}$-Induced Climatic Change, Publ. DOE/EV/60 235-1, Department of Energy, Washington, D. C., 1985.

Radok. U., and R. C. Lile, A year of snow accumulation at Plateau Station, in Meteorological Studies at Platcau Station. Antarctica, Antarcl. Res. Ser., vol. 25, edited by J.A. Businger, pp. 17-26. AGU. Washington. D.C.. 1977.

Rasmusson, E. M., Hydrological application of atmospheric vapour-flux analyses. Operational Hydrol. Rep. 11 . World Meteorological Organization, Geneva, 1977.

Robin, G. de Q., Ice sheets: Isotopes and temperatures. in The Climatic Record in Polar Ice Sheets, edited by G. de Q. Robin. pp. 1-18, Cambridge University Press. New York, 1983.

Robin, G. de Q.. and S. J. Johnsen, Atmospheric processes. in The Climatic Record in Polar Ice Sheets, edited by G. de Q. Robin. pp. 47-52, Cambridge University Press. New York, 1983.

Rogers, J. C., and H. van Loon, Spatial variability of sea level pressure and $500 \mathrm{mb}$ height anomalies over the southern hemisphere, Mon. Weather Rev., 110. 1375-1392, 1982.

Rubin, M. J. . Atmospheric advection and the Antarctic mass and heat budget, in Antarctic Research, Geophys. Monogr. Ser., vol. 7, edited by H. Wexler, M. J. Rubin, and J. E. Caskey, Jr.. pp. 149-159. AGU. Washington. D.C.. 1962.

Rubin. M. J.. and M. B. Giovinetto. Snow accumulation in central West Antarctica as related to atmospheric and topographic factors. J. Gcophys. Res. . 67, 5163-5170. 1962.

Rusin, N. P., Meteorological and Radiational Regime of Antarctica, translated from Russian. Israel Program for Scientific Translations. Jerusalem. 1964.

Sato, N.. K. Kikuchi. S. C. Barnard. and A. W. Hogan, Some characteristic properties of ice crystal precipitation in the summer season at South Pole Station, Antarctica. J. Mereorol. Soc. Jpn.. 59. 772-780, 1981.

Satow. K., Variability of surface mass balance in the Mizuho Plateau, Antarctica, in Proceedings of Seventh Symposium on Polar Meteorology and Glaciology, edited by S. Kawaguchi, pp. 132-140, National Institute of Polar Research, Tokyo, 1985.

Schwerdtfeger. W.. Thoughts about a compensation principle for atmospheric precjpitation (in German), Meteorol. Rundsch., 4, 96-97, 1951 .

Schwerdtfeger, W., The climate of the Antarctic, in Climate of the Polar Regions, World Surv. Clinatol., vol. 14, pp. 253-355. Elsevier, Amsterdam, 1970.

Schwerdtfeger, W., Weather and Climate of the Antarctic, Dev. Aimos. Sci., Vol. 15, Elsevier, New York, 1984.

Sevruk, B., Methods of correction for systematic error in point precipitation measurement for operational use, Operational Hydrol. Rep. 21, World Meteorological Organization, Geneva, 1981.

Sinclair, M. R., Record-high temperatures in the Antarctic - A synoptic case study, Mon. Weather Rev., 109, 2234-2242, 1981.

Smiley, V. N., B. M. Whitcomb. B. M. Morley, and J. A. Warburton, Lidar determinations of atmospheric ice crystal layers at South Pole during clear-sky precipitation, J. Appl. Meteorol., 19, 1074-1090, 1980.

Smith, R. B.. The influence of mountains on the atmosphere, in Adv. Geophys., 21, 87-230, Academic. Orlando. Fla., 1979.

Streten, N. A., Some aspects of high latitude southern hemisphere summer circulation as viewed by ESSA 3, J. Appl. Meteorol., 7. 324-332, 1968.

Streten. N. A., Some synoptic indices of the southern henisphere mean sea level circulation 1972-77, Mon. Weather Rev., 108. 18-36, 1980.

Streten. N. A., and A. J. Troup, A synoptic climatology of satellite cloud vortices over the southern hemisphere, $Q$. J. R. Meteorol. Soc.. 99, 56-72, 1973.

Takahashi. S., Estimation of precipitation from drifting snow observations at Mizuho Station in 1982, in Proceedings of Seventh Symposium on Polar Meteorology and Glaciology, edited by S. Kawaguchi, pp. 123-131, National Institute of Polar Research, Tokyo, 1985.

Taljaard, J. J., H. van Loon. H. L. Crutcher, and R. L. Jenne, Climate of the upper air: Southern hemisphere, vol. I, Temperature. dew points and heights at selected pressure levels. rep. NAVAIR 50-/C-55. Naval Weather Service Command. Washington, D.C., 1969.

Tannehill. I. R., Drought. Its Causes and Effects. Princeton University Press. Princeton. N.J.. 1947.

UNESCO, World Water Balance and Water Resources of the Earth, UNESCO Press. Paris, 1978.

Vickers. W. W.. A study of ice accumulation and tropospheric circulation in West Antarctica. in S/udies in Anfarctic 
Meleorology. Antarct. Res. Ser., vol. 9. edited by M. J. Rubin, pp. 135-176. AGU, Washington. D.C.. 1966.

Vilenskiy, V. D., R. V. Teys, M. A. Kiselevskiy, and S. N. Kochetkova, Origin of the oxygen-isotope composition in the snow cover in East Antarctica, Geochem. Imt., Engl. Transl., 15(2), 180-185, 1978.

Whillans, I. M., Surface mass-balance variability near "Byrd" station, Antarctica, and its importance to ice core stratigraphy, J. Glaciol., 20, 301-310, 1978.

Zillman, J. W., Solar radiation and sea-air interaction south of Australia, in Antarctic Oceanology, II, The AustralianNew Zealand Sector, Antarct. Res. Ser., vol. 19, edited by D. E. Hayes, pp. 11-40, AGU, Washington. D.C., 1972.

D. H. Bromwich, Byrd Polar Research Center, 125 South Oval Mall, Columbus, OH 43210.

(Received August 17, 1987; accepted January 4, 1988.) 